Is Pupil Attainment Higher in Well-managed Schools?

Alex Bryson Lucy Stokes David Wilkinson

Department of Quantitative Social Science Working Paper No. 18-09

Nov 2018 


\section{Disclaimer}

Any opinions expressed here are those of the author(s) and not those of the UCL Institute of Education. Research published in this series may include views on policy, but the institute itself takes no institutional policy positions.

DoQSS Workings Papers often represent preliminary work and are circulated to encourage discussion. Citation of such a paper should account for its provisional character. A revised version may be available directly from the author.

Department of Quantitative Social Science, UCL Institute of Education, University College London, 20 Bedford Way, London WC1H 0AL, UK 


\title{
Is Pupil Attainment Higher in Well-managed Schools?
}

\author{
Alex Bryson ${ }^{1}$, Lucy Stokes ${ }^{2}$ and David Wilkinson ${ }^{3}$
}

\begin{abstract}
Linking the Workplace Employment Relations Surveys 2004 and 2011 to administrative data on pupil attainment in England we examine whether secondary and primary schools who deploy more intensive human resource management (HRM) practices have higher pupil attainment. We find intensive use of HRM practices is positively and significantly correlated with higher labour productivity and quality of provision, and with better financial performance, most notably in primary schools, but it is not associated with higher pupil attainment as indicated by assessment scores at Key Stage 2, Key Stage 4 and value-added measures based on assessments at these points.
\end{abstract}

JEL Codes: 121

Keywords: school performance; pupil attainment; value-added; human resource management

Contact Details: Alex Bryson (a.bryson@ucl.ac.uk), University College London, National Institute of Social and Economic Research and Institute for the Study of Labor

Acknowledgements: We thank the Nuffield Foundation (grant EDU/41926) for funding. The authors acknowledge the Department for Business, Energy and Industrial Strategy, the Economic and Social Research Council, the Advisory, Conciliation and Arbitration Service and the National Institute of Economic and Social Research as the originators of the Workplace Employee Relations Survey data, and the Data Archive at the University of Essex as the distributor of the data. The views expressed are those of the authors, and all errors and omissions remain the sole responsibility of the authors.

\footnotetext{
${ }^{1}$ University College London

${ }^{2}$ National Institute of Social and Economic Research and Institute for the Study of Labor

${ }^{3}$ University College London and National Institute of Social and Economic Research and Institute for the Study of Labor
} 


\section{INTRODUCTION}

In 1985, Richard E. Walton published "From Control to Commitment in the Workplace." The argument was simple: there are often two radically different strategies for managing a workforce. For simplicity, Walton spoke of these profound differences as reflecting the choice between a strategy based on control of workers and a strategy based on eliciting commitment from them. He began the article with a tale of two real-life establishments, each under the control of the same parent firm, but with vastly different management practices, outcomes and employee satisfaction levels (Walton, 1985). ${ }^{4}$ It took empirical researchers nearly a decade or more to appreciate Walton's title, not to mention evaluate or extend his conclusions. During this period, the wide variability in the way employees experience their day-to-day working lives (Green and Whitfield, 2009; Addison et al., 2013; Forth, Bryson and George, 2017) became increasingly apparent; i.e., variation that today is observable not only across industries but also within firms (Barth et al., 2016).

This variation in workplace quality, evidenced in both qualitative and quantitative accounts, is especially pertinent in countries like Britain, where sectoral bargaining is rare, employer associations are weak and union coverage rates low (Traxler, 1995; Teulings, and Hartog, 1998; Traxler et al, 2001; Addison et al., 2013; Bryson et al., 2017). In this context, the question becomes how to understand the nature of employee well-being when localmanagement has such a wide degree of discretion?

\footnotetext{
${ }^{4}$ Recent research by Barth, Bryson, Davis and Freeman (2016) has focused on the role of "establishment" level processes that lead to earnings inequality. This is added confirmation for the role played by firm and workplace level heterogeneity in determining labour market outcomes. The related role of "strategic choice" in industrial relations is most often associated with the Industrial Relations section at MIT and their early 1980s work on "US Industrial Relations in Transition" funded by the Alfred P. Sloan Foundation (see Kochan et al., 1984). Their work pushed industrial relations away from the traditional confines of "industry structure" as the key determinant of labour market outcomes towards the "firm" level determinants of managerial quality and strategy. In the late 1990s, with the rise of detailed employer and workplace data such as the British Workplace Employment Relations Survey (WERS), workplace level heterogeneity (conditioning on parent firm) emerged (See Forth and McNabb, 2008). The new idea of management as "technology" is further confirmation of the variation in outcomes linked to workplaces-level decision-making (Bloom and Van Reenan, 2016).
} 
Until recently, two approaches have dominated the study of employee well-being and job satisfaction in Anglo-American economies. The first focuses on the correlates of poor working conditions and how these might be offset through job design/enrichment schemes (Hackman and Oldham, 1976; Morgeson et al., 2006) and/or better managerial practices and ‘technologies' (Black and Lynch, 2001; Bloom and Van Reenen, 2010; Bloom et al., 2012). The other approach, rooted in employment relations scholarship, examines how workplace outcomes can be improved through employee voice and involvement at work (Guest and Pecci, 2001; Bryson, Charlwood and Forth, 2006; Addison 2009).

With respect to the latter, apart from some notable exceptions (see Taras and Kaufman, 2006; Gollan, Kaufman, Taras and Wilkinson, 2015; Kaufman, 2017), studies of unionism have dominated the employment relations/worker representation literature. This is partly because as an institution, even as membership and coverage have declined, unionisation is still the dominant form of representative voice in most Anglo-American countries. There is also evidence that unions, at least in Britain and the United States, tend to form as a response to poor working conditions (Bryson and Freeman, 2013). The idea is that through the provision of collective bargaining and grievance systems, unionised workers gain a modicum of "voice" which they can then use to improve working conditions and solve the public-good provision problem common in 'voluntary' forms of collective action (Booth 1985, 1995). Unionisation should therefore lead to improved well-being for workers and a positive association between unionism and measured job satisfaction. ${ }^{5}$

\footnotetext{
${ }^{5}$ The fact that union members were originally found to be less satisfied in their jobs was a bit of a puzzle to labour relations scholars, further exacerbated by the fact that unionised workers were (and still are) simultaneously less likely than non-union workers to quit their jobs (Freeman, 1978; Borjas, 1979). Evidence has emerged since those early union-satisfaction studies, however, showing that it is a combination of the unionised job itself (Pfeffer et al., 1990; Artz, 2010; Bryson et al, 2010) and attributes of workers prone to unionising (Larcohe, 2016; Bryson and White, 2016a) that can account for the bulk of the union-job satisfaction paradox. Once those factors are captured in estimates, the negative union-satisfaction association goes away and in some cases even turns positive (Laroche, 2017).
} 
This emphasis on employee satisfaction is important as a growing number of recent studies are establishing 'causal' linkages between worker well-being and individual productivity (Oswald, 2015) as well as between employee job satisfaction and establishmentlevel performance (Bockerman and IImakunnas, 2012; Bryson, Forth and Stokes, 2017). The question in this paper is whether non-union voice -- if formally established at the workplace through some kind of joint consultation committee or employee forum -- is similarly associated with better employee outcomes and greater job satisfaction.

Unfortunately, this is not a question with a ready-made answer, as there are virtually no large-scale empirical studies, beyond case analyses (Gollan et al., 2015; Kaufman, 2017), relating non-union representation to employee well-being or job satisfaction (Wilkinson et al., 2018b). As noted by one recent study, there is a lack more generally of empirical research "into the prevalence, determinants and outcomes of [non-union] employee representation at the workplace-level" (Forth et al., 2017). Instead, the non-union voice literature in Europe focuses on German codetermination /works councils (Addisson, 2009) or "investigations of the structures and outcomes of social dialogue at sectoral and national levels" (see Keller and Weber, 2011). In Britain, the literature has historically been concerned with the potential threat that non-union voice plays in relation to traditional unionisation (Danford et al., 2005; Brewster et al., 2007).

In this paper, we address the lack of empirical evidence between non-union voice and employee ratings of management and the job, by focusing on a British variant of the Germanstyle works council, i.e., the joint consultative committee (JCC) or employee forum. We focus on JCCs whilst controlling for the presence of traditional collective bargaining and human resource practices that independently provide voice and employee involvement/commitment. Using a new and unique cross-national dataset - the State of the Workplace Employment Relations Survey (SWERS) - we investigate the role that JCCs play 
in what workers themselves tell us are "good" places to work. ${ }^{6}$ We draw from a representative sample of British workers found in SWERS focusing on questions that capture the nature of the employment relationship and access to voice. SWERS has already been used in an Australian study of employer and workplace outcomes (Wilkinson et al., 2018a), but has hitherto been unused in Britain.

In addition to following the traditional literature that links union representation with self-assessments of working conditions, a secondary focus of the paper is to distinguish nonunion consultative voice from seemingly 'similar' high involvement human resource (HIHR) practices. ${ }^{7}$ Despite the often blurred use of terms such as 'high-performance' to mean 'highcommitment' or 'high-involvement' (Kaufman, 2012) ${ }^{8}$, we focus only on management practices that are associated with enhanced employee involvement, thereby excluding from this definition pure "high-performance" techniques such as selective recruitment, performance appraisals, incentive pay and so on. Our focus on involvement-led HR is also distinguishable from the recent literature depicting management as a 'technology' (Bloom et al., 2017). This management-as-technology literature has a distinctive 'industrial engineering/scientific management' feel with its emphasis on target setting, high-powered incentives and monitoring (Bryson, 2017; Bloom and Van Reenen, 2011).

The added motivation for including HIHR as an "independent" predictor of employee assessments of work and management is that this relationship is still contested in the

\footnotetext{
${ }^{6}$ A recent literature in the United States - and research program based at the Great Place to Work Institute ${ }^{\mathrm{TM}}$-has focused on the "good workplace" and those employer practices that are associated with a host of positive employee and employer outcomes (Kruse, Freeman and Blasi, 2010, 2015).

See: http://www.greatplacetowork.co.uk/index.php

7 There is equal usage of the terms "high-involvement", "high-commitment" and "high-performance" in the literature stemming from the original authorship in the area (e.g., Walton, 1985; Lawler, 1986; Kochan and Osterman, 1994; and Applebaum et al., 2000). We view the first two as interchangeable for the purposes of this study and will use HIHRM as shorthand for these studies.

${ }^{8}$ In Kaufman (2012) the 'fuzzy' and often blurred terminology used in much HR scholarship is critiqued more fully.
} 
literature. While many features of HIHR can drive up job quality -- enriching workers' experience and at the same improving workplace performance (Parker and Wall, 1998; Kochan and Osterman, 1994; Applebaum et al., 2000; Saridakis et al., 2017; Bryson, 2017) -there is also, if implemented poorly, the labour intensification potential of "highinvolvement" practices. These can result in adverse consequences for workers including poor health, increased risk of injury, greater absenteeism and turnover (Pfeffer, 2018; Godard, 2004; Ramsay, Scholarios and Harley, 2000).

The paper proceeds as follows. Section 2 reviews the existing literature on non-union voice in the British context (that is, works councils versus joint consultative committees) and explores the potential interactions these institutions might have with collective bargaining coverage and high-involvement HR. Section 3 describes the SWERS dataset, together with the specific measures of worker representation and HR used in the analysis, and outlines the methods employed in our quantitative analysis. Section 4 presents the results of our analysis. Section 5 concludes and discusses some of the implications of the analysis.

\section{THEORETICAL BACKGROUND AND EXISTING EVIDENCE}

There are two main areas of literature that this paper adds to. The first concerns itself with our primary outcome, subjective assessments of worker well-being, summarized here as overall employee or job satisfaction, which collectively might be considered as an appraisal of the workplace as a whole. The second is the non-union voice literature as it pertains to Britain, which historically has been studied under the banner of 'joint consultation' (Johnson, 1952; Wheelwright, E, 1954; Joyce and Woods, 1984; Gospel and Willman, 2003).

Beginning with the former, the employee job satisfaction literature is vast and at this point decades removed from the original labour economics literature (Freeman, 1978; Borjas, 1979) and the management field experiments which it spawned (Hackman and Oldham, 1976; Fried and Ferris, 1987). In short, it is not reducible for the purposes of this paper. 
There is a subset of this literature, however, which is more managable and which relates to the objectives of the paper; i.e., studies relating unionism or management practices to worker satisfaction (Böckerman, Bryson and IIlmakunnas, 2012). The fact that the two areas - union and HRM impacts on employee satisfaction -- are rarely studied together limits our pool of relevant literature even further (see Pohler and Luchak, 2014).

Surprisingly, non-union employee representation, though re-emerging in Britain as an area of active research, is virtually unexplored in the employee satisfaction literature. Our study fills this gap by linking what is already known from the union and HR studies on employee satisfaction to the hypothesized relationship between workplace consultation and subjective worker well-being. The focus is on what occurs at the workplace and employee perceptions of what is "good" in that context.

Finally, there is a literature which has examined the substitutability/complementarity of non-union voice and HR practices with respect to union membership (Brewster et al, 2007), which here too has some relevance since the three institutions - JCCs, unions, and HR -- are studied in concert. We begin with a brief summary of joint consultation in Britain and then propose a series of four hypotheses that relate employee satisfaction to JCCs and our two other workplace institutions.

\subsection{The Practice of Joint Consultation in Britain, 1916 to the Present}

There is a long history with worker consultation in Britain. It stretches back to the early part of the 20th century when labour-related conflict spawned a welfare capitalist movement intent on preserving the market economy but infusing it with a strong dose of industrial democracy (Webb and Webb, 1897; Poole, 1986; 1989; Frege 2005). The early proponents of consultative systems were not intent on replacing collective bargaining or management-led approaches, rather they envisaged a third pillar upon which worker-management relations could stand to overcome problems of mutual interest and benefit. 
This achieved most fulsome expression in the British civil service under what became known as the "Whitley system"; named after J.H. Whitley who was Chairman of House of Commons Committees and later its Speaker in the early 1900s. In 1916, in what at the time was described as an atmosphere "idealism" and post-war "reconstruction" planning (Wheelwright, 1954), a Cabinet Committee on Reconstruction was set up with the title "The Committee on Relations between Employers and Employed”. Whitley was Chairman of this committee and charged it with recommending ways of achieving permanent improvement in industrial relations. The Whitley report proposed that a series of committees be set up in each industry, made up of employee and management representatives, in order to exchange information and deal with issues of mutual relevance. Emphasis was laid on the principle of "self-government in industry" (Johnson, 1952) and these Whitley Councils, as they became known, were to appear at three levels: national, district and workplace level. They were adopted rather quickly in the Civil Service, and judging by the most recent estimates of JCC presence in Britain, there is still a legacy effect present in the public sector. As noted in a recent review of consultation systems in Britain (Adam, Purcell and Hall, 2014), JCC presence of any kind (workplace or higher) is three times greater in the public sector than in private industry (i.e., present in 65 percent of public sector establishments versus 20 percent respectively in private industry).

Despite the 'success' in the Civil Service, "Whitleyism" never fully took hold elsewhere. While the Government of the day accepted the report and recommended the establishment of National Joint Industrial Councils, it left it up to employers and trade unions to adopt the consultative scheme to their own requirements. Most simply ignored the consultative dimensions and the ones that did establish a council, established traditional collective bargaining relationships within them (Gospel and Willman, 2003). During the interwar depression and industrial unrest of the 1920s, both institutions - collective bargaining and consultation -- contracted even further. Yet, despite falling far short of its 
original purpose, joint consultation left its mark on industrial relations in Britain. The joint industrial councils were revived and actively supported by government during the 1930 s and 1940s in response to the Second World War and were once again used to "aid in reconstruction" efforts afterwards (Milner, 1995). Moreover, even as this phase of joint consultation waned in the face of post-war demands by unions for traditional collective bargaining and employer reticence to accept workplace level representation, the institution never fully faded away. In fact, well into the 1970s, worker representation was a live political issue. There were demands for the establishment of worker representation on the board of firms in publicly owned industries (Batstone et al., 1983) and tripartite arrangements such as the 1974 Health and Safety at Work Act (HSWA) led to the emergence of important consultative structures at workplace level (Poole, 1986).

By the early 1980s, however, the political environment towards industrial democracy and collective bargaining had changed markedly. With the election of Margaret Thatcher and her government's removal of immunities and imposition of restrictions on union activities, membership and union coverage began to shrink almost immediately. ${ }^{9}$ It was at this time, however, that employers became increasingly interested in 'alternative voice' systems, in part to fill the void left by a lack of trade union representation but also as part of a broader strategy of management-led employee engagement strategies. Even though it is clear from various waves of the British Workplace Employment Relations Survey (WERS) that employers have, at least since the 1980s, favoured direct forms of communication (e.g., via worker meetings, problem-solving circles and briefing groups etc.) over union and non-union representative voice; joint consultative committees (JCC) have always remained an option (Bryson, Willman, Gomez and Kretschmer, 2013).

\footnotetext{
9 There is, of course, debate about the degree to which union decline was precipitated by legislative change, or whether legislative change simply reflected other forces at play (Freeman and Pelletier, 1990).
} 
From the early 2000s onward, when Tony Blair's New Labour Government adopted the EU Directive on Information and Consultation of Employees (ICE), joint consultation through the vestige of the JCC system, was once again poised to re-emerge. Interestingly, the stated commitment to consultative structures at the workplace has grown even further under Theresa May’s leadership of the Tory party- e.g., Prime Minister May made worker representation in industry a priority of her stillborn campaign for leadership of the party ${ }^{10}$ and has followed through with the commissioning of the 2017 Taylor Review; two in a series of indications that "employee voice" is squarely on the agenda of the Government (O'Connor, 2017). It is also the case that trade unions and employers are not, as was previously the case, in opposition mode to these proposals (O’Connor, 2017). Studies taking a closer look at employee involvement and consultative voice in the form traditionally found in Britain through joint consultation committees- are therefore particularly relevant now.

\subsection{Employee Satisfaction: The Role of Union and Non-Union Worker Voice}

What is the relationship between non-union voice and employee satisfaction? As noted in the introduction, the empirical literature has historically been somewhat mixed when it comes to relating employee satisfaction to union membership (Bryson, Cappellari, and Lucifora, 2010; Green and Heywood, 2015), with a majority of the early studies finding a negative correlation between job satisfaction and unionisation (Bryson et al., 2004). The reasons are many and summarised in a recent meta-analysis of the union job satisfaction literature (Laroche, 2016): e.g., union ineffectiveness in fixing underlying managerial problems, union effectiveness and

\footnotetext{
${ }^{10}$ Even though she was acclaimed when her only opponent bowed out of the race for party leader, Theresa May's first and only speech of that campaign on July 11, 2016 had some direct language regarding the role of employees in company decision making: "And I want to see changes in the way that big business is governed. The people who run big businesses are supposed to be accountable to outsiders, to non-executive directors, who are supposed to ask the difficult questions, think about the long-term and defend the interests of shareholders. In practice, they are drawn from the same, narrow social and professional circles as the executive team and - as we have seen time and time again - the scrutiny they provide is just not good enough. So if I'm Prime Minister, we're going to change that system - and we're going to have not just consumers represented on company boards, but employees as well." (UKPOL, 2016)
} 
the raising of expectations; unions' ability in securing job security and increasing tenure hence inducing voice-related complaining; or sorting by worker-type (e.g., less 'agreeable' workers tend to prefer unions).

More recently, the inclusion of relevant conditioning variables and efforts to overcome perennial endogeneity problems associated with union organizing in the face of already poor performing firms and less agreeable 'voice-prone' workers, have found positive union associations with pay satisfaction and other aspects of the job (Hipp and Givan 2015; Bryson and White, 2016a, 2016b; Laroche, 2016, 2017). This gives rise to the following hypothesis:

Hypothesis 1: In unconditional cross-section estimates, the union-employee satisfaction relationship is likely to be negative. With our full set of controls and typically 'hard-to-observe' worker attitudes added to standard multivariate analyses, the relationship between unionisation and employee satisfaction is expected to turn positive.

Interestingly, the new empirical studies establishing neutral or positive associations between unions and employee satisfaction have appeared at the tail end of a steep decline in the number of workers covered by collective agreements in Britain (Bryson, Freeman, Gomez and Willman, 2017). And yet, British employers appear to still value worker input into decision making processes, as evidenced by the fact that since the early 1980 s the percentage of workplaces (and workers) with no formal mechanisms for employees to express their voice has remained steady at around 20 percent (Willman et al., 2006; Bryson, 2017). This is due to the surge in non-union forms of voice, most of which involve direct forms of two-way communication between employees and management but which include representative structures as well (Gollan et al., 2015).

The literature on non-union representative voice has tended to focus on works councils (WCs), mainly in Germany where they have a long history and are underpinned by statutory protection (Frege, 2002; Addison, 2009). In Britain, by contrast, the equivalent of works councils - joint consultative committees (JCCs) -- have only recently come under 
active scrutiny, in part because they are often seen as creatures of the employer with traditionally little or no legal support and no real say over key aspects of decision-making at the workplace (Dobbins and Gunnigle, 2009).

Yet evidence from recent papers suggests that workplace consultation and meaningful engagement, even in the Anglo-American world where it is often thought to be insufficient, might play a more important role than previously thought (Wilkinson et al., 2014; Bryson, 2017). In particular, the presence of non-union voice (JCC/employee forum) with (or without) unionisation seems to impart a significant advantage in organizational and employee outcomes, as compared to firms with no representation whatsoever (Wilkinson et al., 2018). This is suggestive that the two forms of representation - union and JCCs -- are complements and not substitutes as has often been assumed in the literature (Brewster et al., 2007; Machin and Wood, 2005; Godard, 2007). The question increasingly appears to be how faithfully do JCC's reflect joint employee-employer concerns and how do management techniques and unions assist (or detract from) these parallel consultative workplace institutions (French, 2001; Brewster et al., 2007; Pohler and Luchak, 2014)?

This gives rise to the second hypothesis tested in the paper:

Hypothesis 2: In both unconditional and conditional estimates, the relationship between non-union voice - as measured by the presence of a joint consultative committee (JCC) at work - and employee satisfaction should be positive. We do not expect the relationship to be strongly mediated by union presence or HIHR, meaning that we should not see the coefficient size diminish (or significance levels to drop) when union presence and HIHR are controlled for.

\subsection{Employee Satisfaction: The Role of Management Practices}

The main contention of the 'mutual gains' literature (Kochan and Osterman, 1994) is that firms and their employees benefit from the adoption of progressive employee management practices. These practices have a separate and earlier history and are known as "highinvolvement", "high commitment" or "high performance" workplace practices (Walton, 1985; Lawler, 1986; Appelbaum, 2000), though the latter term has problems in that it 
sometimes conflates performance-management with employee engagement. For firms, the benefits of a "commitment" over "control" approach accrue through improvements in labour productivity and profitability, while for employees they arise through intrinsic rewards related to engaging in enjoyable work, controlling their own working environment, having a "say" at work more generally, and feeling part of the enterprise.

The literature on these new-style HR management practices, though contested (Kaufman, 2012), has developed rapidly in the intervening quarter century, particularly in economics, where the study of internal management had long been neglected (Grund et al., 2017; Lazear 2000). The study of "management" is no longer the preserve of business school gurus and managerial scientists. Instead, it is recognised as a key input into the production process, i.e. a 'technology' entering the production function alongside capital and labour (Bloom and Van Reenen 2012 (BVR forthwith)). However, the practices deemed critical in this framework are not necessarily those likely to offer a 'say at work' or elicit employee engagement. For BVR the core set of practices are target setting, monitoring, and high-powered incentives - arguably the pillars of the scientific management orientation propounded by Taylor and adopted by generations of industrial engineers. BVR find strong correlations between these practices and firm productivity and performance within and across countries (Bloom et al., 2014). Indeed, they argue differences in managerial practices account for a substantial part of the variance in productivity across firms within industries, thus helping to explain the huge heterogeneity in firm performance within industries and some firms emphasised by recent scholarship (Syverson, 2011). BVR maintain these practices are not simply correlated with better performance, rather they have a causal impact on productivity and performance (Bloom et al., 2017).

This is a controversial stance. Others argue that what works for some firms may not work for others, either because the success of management practices is contingent on a set 
of "hidden from view" attributes such as firms' competitive strategies, or because they are contingent on the other policies and practices deployed by the firm-what are referred to as external and internal fit respectively (Milgrom and Roberts, 1995; Huselid, 1995; Becker and Huselid, 1998). The implications are that firms may need to experiment with various practices before identifying what works for them, while the internal fit perspective suggests the precise configuration of HRM practices is likely to matter.

Notwithstanding these objections, if the sub-set of practices emphasised by BVR are so successful, one might question the value of engaging employees through a more extensive set of practices, even if they do benefit employees. The core HR practices highlighted in the early high commitment management literature were those that transformed job and work organization through the devolution of control to workers, offering the autonomy required to optimise their own working arrangements (Lawler, 1986; Walton, 1985). Additional support, through on-going training, is thought necessary to underpin the transition to such a system and maintain it in the face of worker turnover and modifications to production (Forth and Millward, 2004; Appelbaum et al., 2000). This 'highinvolvement' HR model is a fundamentally different perspective on what might "work" when compared to BVR's conception, stemming largely from the assumption that performance improvements brought about by transforming HR occur because they engage employees in their jobs and consult them in decision-making more generally at the workplace.

Although there is debate about the optimal configuration of HR practices and whether the returns to such practices are homogeneous across firms and workplaces, there is increasing evidence to suggest that firms can and often do increase productivity via investments in high-involvement HR practices. There are studies in addition to BVR's to suggest this is the case, and many of these include a more complete set of HR practices than those used by BVR, including those that have the potential to raise employee involvement 
(see reviews by Wood and Bryson, 2009; Bloom and Van Reenen, 2011; Saridakis et al., 2017).

In terms of the mechanisms by which commitment-led HR improves productivity there is suggestive evidence that it accrues through employee engagement and through improvements in workers' well-being. One study has identified a causal linkage between individual worker happiness and individual productivity (Oswald et al., 2015) while other recent studies suggest this link also exists at an organizational level (Bryson et al., 2017; Böckerman and Ilmakunnas, 2012).

It is therefore possible that the high-involvement variant of HR management benefits firms by increasing worker wellbeing first. The literature on links between HR practices and employee wellbeing also suggests that what matters is the intensity with which the HR system is implemented by management: i.e., "shallow" or "below average" HR adoption can actually reduce employees' intrinsic job satisfaction and organizational commitment $^{11}$, while more intensive high-involvement HR use is positively associated with both outcomes (White and Bryson, 2013).

This gives rise to the third hypothesis tested in the paper:

Hypothesis 3: In both unconditional and conditional estimates, the relationship between above-average high-involvement human resource (HIHR) practice adoption and employee satisfaction should be positive. We do not expect the relationship to be strongly mediated by JCCs and union presence, meaning that we should not see the coefficient size diminish (nor significance levels drop) when JCCs and union presence are controlled for.

\subsection{Possible Interaction Effects}

The theory and evidence surveyed above is suggestive that joint consultation, union representation and high-involvement $\mathrm{HR}$ are all related to employee satisfaction in a positive

\footnotetext{
${ }^{11}$ One could speculate on the mechanisms at work but it is likely that half-hearted attempts to introduce highinvolvement HR are seen accurately by employees as a means to extract more effort for less reward, while another mechanism may simply be a signal of poor managerial capacity and skill.
} 
manner, with the 'trickiest' relationship involving unions. Given the strong selection and endogeneity effects associated with the union relationship (Laroche, 2017), the unconditional estimates are likely to be negative (as has been found in the prior literature). But when using a set of controls that capture most of the job-related and attitudinal dispositions of workers associated with more negative appraisals of the workplace (as is now common in the recent literature), there is likely to be a small but positive relationship between union coverage and employees' wellbeing in cross-sectional estimates. ${ }^{12}$

The other two main-effect relationships with respect to employee satisfactionbetween joint consultation and high-involvement HR respectively - are expected to be positive, so the question is whether the positive coefficients remain empirically relevant when all three workplace-based institutions are simultaneously estimated. If one or the other reduces in magnitude, there would be evidence of 'mediation' at work, something that may be plausible if one considers that if high-involvement HR is in place and actually works, a separate conduit for employee consultation (i.e., a JCC) may not be as necessary or impactful.

Perhaps more important than even the main-effect and mediating relationships, are the possible synergies between union representation, high-involvement HR and JCCs, in which case we need to be attentive to the potential for interaction/moderation effects. In our case, the relationship between JCCs and overall employee workplace satisfaction could be moderated by union presence, but it may also be moderated by HIHR: e.g., workers in HIHR workplaces may have more to gain from having a JCC present. Moreover, the moderating effect of union presence may itself depend on HIHR presence (or lack thereof); i.e., even if the worker is unionised, they may not be able to feel the benefits of a JCC if they work for a 'control' versus 'commitment' employer, whereas if they have a very high-involvement employer but are not unionised, the role of a JCC may be exacerbated beyond that predicted

\footnotetext{
12 In adding right-hand side variables to regression estimate, we are of course mindful of the dangers of overcontrolling (i.e., using endogenous variables which obfuscate some of the union transmission mechanisms.
} 
by either moderator alone. There is also finally the 'black hole' (Guest and Conway, 1999) or 'silent' (Willman, Gomez, and Bryson, 2006) workplace where no evidence of any formal HR system (progressive or otherwise) or union voice is found. Measured against this comparator, one would expect to find a marked difference in employee satisfaction scores amongst respondents with access to a JCC or with access to all three systems versus those with none.

The question is how robust to the inclusion of control variables and interactions with the two other workplace institutions - high-involvement HR and/or union representation will the JCC relationship be? We do not believe that the evidence, however scant, is suggestive of a fully moderating relationship between JCCs and the presence a union or highinvolvement HR. Our review of the literature suggests that there is a direct benefit from having a JCC that should remain salient in estimates where all three dual interactions are controlled for and when we estimate the coefficient attached to having all three systems in place.

This gives rise to our fourth and final hypothesis:

Hypothesis 4: When JCCs are found in combination with both union presence and above average high-involvement HR (in a three-way interaction term), the moderation/interaction effects with respect to employee satisfaction are likely to be positive but not strong enough to reduce the independent or 'main effects' of joint consultation and high-involvement $\mathrm{HR}$.

\section{DATA AND METHODS}

\subsection{The Data}

The data used in this study were obtained through a custom-designed survey instrument, the State of the Workplace Employment Relations Survey (SWERS). The survey itself comes from a broader project funded by the Australian Research Council (ARC), Social Science and Humanities Research Council (SSHRC in Canada) and Industrial Relations Counsellors (IRC in the USA) examining employment relations outcomes in four countries: Australia, United States, Britain and Canada including nationally representative surveys of employees and 
managers. Unlike past employee voice surveys the entirety of the employment relationship as well as relevant worker and employer outcomes, rather than simply representation and participation, was covered.

The employee surveys were given to separate panels of respondents in the four countries pre-assembled by a professional organisation survey company, Opinion Research Corporation (ORC), who conducted the survey on our behalf. The survey research firm, considered a world leader in this technique, has a large representative panel of employees and managers in all four counties. It then blends in requests to other panel members having the needed characteristics until an (approximately) nationally representative sample is obtained over key observables, which in our case were standard demographics for employees (e.g., age, gender, marital status, immigrant status, education) and for employers encompassed industry and workplace size. This is in effect a form of 'quota sampling' with online (as opposed to telephone) respondents. Quota sampling does not have a sampling frame and as such does not generate a response rate since there is no randomly drawn target sample from which a proportion of valid responses can be drawn (Dodge, 2006: 428).

The surveys were completed in 2016 with a sample of roughly 2000 employees from each of the four countries. In this paper, respondents from workplaces with more than 20 employees were included as we wanted to engage with workplaces of sufficient size to have some chance of having formalised workplace systems in place. This paper uses only the British employee data from SWERS, giving us a sample of 2,042 employees. ${ }^{13}$

\subsection{Measures and Methodology}

Key Dependent Variables

${ }^{13}$ In this study we do not use the employer survey which includes 415 respondents. 
As we are interested in estimating the relationship between JCCs and employee satisfaction, whilst controlling for any mediating or moderating associations among union representation and high-involvement HR practices, it is necessary in our case to be able to collapse a series of questions that identify employee satisfaction into composite scores so that they can be used as singular dependent variables in the analysis.

To achieve this, we first separate questions that ask about fixed characteristics of the workplace and management from those that ask about attitudes or impressions of management and work. Of the 84 questions asked in the SWERS survey about jobs and the workplace, we identified 16 questions as being 'strongly' attitudinal in nature, and hence candidates for our employee satisfaction measure.

As a second step, we run factor analysis on these 16 questions, which are all based on the same 1 to 7 ordinal scale running from 'strongly disagree' to 'agree strongly', and find that they fall into two separate factors: one for attitudes towards the job (7 questions) and another for attitudes towards management (9 questions). Both factors have Cronbach alphas over 0.90. The two factors were also highly correlated with each other, with a correlation coefficient of 0.82, suggesting that a latent "overall employee satisfaction score" was also present.

Table 1 presents the 16 questions asked in the survey split by our two factors: factor one that picks up employee attitudes towards managers, which includes questions related to 'whether individual managers work hard to motivate and engage employees at work' and 'whether employees have confidence in their management team'. The second factor is a variable capturing employee attitudes towards the job itself and includes measures such as 'how satisfied the employee is about his or her job', and 'how attached he or she is to their work'. Based on the high correlation between these two measures of satisfaction (with the "job" and with "management") we also create an overall employee or workplace satisfaction variable by taking the average score rating of the two dependent variables.

[Table 1] 


\section{Key Independent Variables}

Our measure for the presence of non-union voice comes from a question that asks employees if the workplace has an internal joint consultative committee (JCC) that meets to discuss workplace/employment issues. Specifically, respondents are coded 1 if they answer 'yes' to the following question: "Has management put in place for employee consultation and voice some kind of internal joint consultative committee, staff advisory association, plant council, or workplace employee forum so managers and elected/selected employee representatives can meet and discuss issues of relevance?" and 0 otherwise. ${ }^{14}$

Similarly, to capture the relationship between unionisation on employee attitudes, we look at respondents that responded affirmatively to whether they were represented by a union at their current unit or workplace. These individuals were coded 1 if they said 'yes' and 0 otherwise ('don't knows' and non-responders were excluded from the analysis).

The last of the three core independent variables in our analysis is the high-involvement human resource (HIHR) variable, which is a composite variable of 6 questions pertaining to high-involvement management policies. The 6 items do appear to be picking up the same latent construct, as evidenced by a Cronbach alpha of 0.89 . Table 2 describes the questions used in this composite HIHR score. As all of these questions are on 1-7 scales, the hihrm variable is defined as:

$$
\text { hihrm }_{i}=\left\{\begin{array}{l}
1, \text { hihrm } \text { score }>\text { median hihrm } \text { score } \\
0, \text { otherwise }
\end{array}\right.
$$

The use of a "threshold" which is converted to a 1 or 0 outcome is in keeping with the way we coded union and JCC presence and also with the notion developed in Section 2 that "shallow"

\footnotetext{
14 Because of a large number of "don't knows" and non-responders to the non-union "consultative committee question", our sample estimates in the regressions were initially reduced to 1,461 employees There is as always the potential of selection bias if these observations were dropped given the fairly large non-response on the JCC measure. In the end we included the "don't knows" as a missing category dummy variable in all the estimates to preserve the sample size (see Tables 5, A1 and A2). Estimates were also carried out where the "don't knows" were deleted from the analysis and the results do not differ appreciably from the results presented here.
} 
HR can actually reduce employees' intrinsic job satisfaction and organizational commitment, but more intensive HRM use is positively associated with both in the literature (White and Bryson, 2013).

Thus, our empirical specification is as follows:

[2]

$$
\begin{gathered}
\text { satisfaction }_{i=}=\pi_{1} \text { committe }_{i}+\pi_{2} \text { union }_{i}+\pi_{3} \text { hihrm }_{i}+\lambda Z^{\prime} \text { twoway }_{i} \\
+\beta\left(\text { union }_{i} \times \text { committe }_{i} \times \text { hpw }_{i}\right)+\gamma X_{i}+u_{i}
\end{gathered}
$$

where satisfaction $i$ represents any of our three measures of employee satisfaction (e.g., attitudes towards management, the job, and an overall workplace satisfaction score), $Z_{i}$ is a vector of all three of our two-way interactions between union $_{i}$, committe $_{i}$, and hihrm $_{i}$, and $X_{i}$ is a vector of relevant covariates. Two key parameters in our regression specification are therefore $\pi_{1}$ and $\beta$, which identifies the main-effect of JCC presence and the three-way interaction estimate of unions, joint-consultative committees and HIHR on employee assessments of their workplace. If the inclusion of union $_{i} \times$ committe $_{i} \times h p w s_{i}$ yields a $\beta$ coefficient that is significant and large, whilst also pulling down any estimate of $\pi_{1}$ it would point to a strong moderation effect at work with respect to JCCs and our other two workplacebased institutions.

\section{[Table 2]}

To control for heterogeneity that may potentially confound the relationship between committee, union, HIHR and our dependent variables, we include four categories of covariates in our vector $X_{i}$ : a) worker demographics, b) workplace/job characteristics, c) market / industry characteristics and d) typically hard-to-observe personal preferences. Worker demographics include information on gender, age, education, occupation, race, immigrant status and marital status, as these are all factors related to the employee that may play a role in the model. Workplace characteristics include variables such as the employee's tenure at the organization, 
organization size and ownership structure (e.g., private, public, not-for-profit). We also control for market characteristics that may affect the organization by controlling for the type of industry and whether the employee's workplace went through a major disruption such as a reorganization, downsizing, bankruptcy etc.. Lastly, despite this being a cross-sectional dataset, we can control for typically hard-to-observe 'fixed-attributes' of individual respondents via self-reported questions that capture whether a respondent prefers "moving often between employers/jobs" (versus remaining loyal to their existing employer) and whether they have a strong "belief in a free market economy" (over a mixed or more publicly controlled economic system).

\subsection{Empirical Caveats}

We are unable to make causal inferences about the relationship between workplace characteristics and employee ratings of their working environment because our data do not permit us to take account of non-random worker sorting across workplaces which may be linked to the sort of ratings they provide. Nor can we account for non-random employer selection of workers from the queue of those wishing to work at their workplace. We know from other studies that this type of sorting does take place. For instance, past research shows that more (less) able workers tend to sort into (out of) workplaces offering performancerelated pay (Lazear, 1990), while other studies depict a queue for union jobs comprised of those in the lower half of the ability distribution, from which employers pick the most able, resulting in positive-selection into union workplaces from the middle of the ability distribution (Abowd and Farber, 1982). These sorting processes can affect employees' ratings of their jobs and workplaces if they are (un)successful in obtaining the sort of job match they would prefer. Similarly, employers may choose HR practices to 'fit' with the workers they are able to recruit. If they are successful in this and workers are exposed to the sorts of HR practices deemed fit for them, this may lead to a higher employee rating for those practices 
than if a random worker had been exposed to them. With these caveats in mind, we can still compare unconditional estimates of the relationship between JCCs and employee satisfaction against estimates conditioned on a fulsome set of controls as well as any potential moderating effects based on interactions with union presence and management-led involvement schemes.

\section{RESULTS}

\subsection{Descriptive Statistics}

Table 3 uses data from SWERS to illustrate the overall and relative satisfaction of workers in Britain. It offers a descriptive breakdown of our independent variables by looking at the data through the presence (or lack thereof) of our three key explanatory variables - i.e., union recognition, JCC and HIHR management. The final column of the Table reports the results for the full sample as a comparison.

[Table 3]

Looking across the first three rows of Table 3 one sees the mean ratings of our dependent measures of employee satisfaction: i) satisfaction with the job, ii) satisfaction with management, and iii) overall satisfaction with the workplace, which is a composite of the two former measures. They show for the most part that union versus non-union workers (column 1) demonstrate very little obvious differences in satisfaction levels whereas the presence of a joint-consultative committee (column 2) or a high-involvement management approach (column 3) are associated with noticeably (positive) differences in mean scores as compared to employees without these workplace systems/institutions. The three-way interaction in column 4 - that is having union recognition, joint consultation and high-involvement management at your workplace (which is 11 percent of our sample, see Table 4 last row)displays the highest relative satisfaction scores (5.35 out of a possible score of 7 ). This is suggestive of positive synergies when all three key independent variables are found present together; whether this is a significant moderating (interaction) effect remains to be seen, as 
we still have to conduct regression estimates that control for observed differences in other relevant independent variables and all two-way interactions.

The lower rows of Table 3 display sample means of our independent variables, again split by the presence (or lack thereof) of union recognition, joint consultation or a highinvolvement management approach. Some regularities deserve mentioning: e.g., employees with union presence and joint consultation tend to be older (29 and 27 percent of the union and JCC sample are aged 55 plus versus 21 and 25 percent in the respective non-union and no JCC categories) and more likely to be found in larger workplaces (43 and 44 percent of the union and JCC employee sample are found in employers with more than 5,000 employees versus 33 and 27 respectively in the non-union and no-JCC sample). The high-involvement HR group appears to differ from JCC and union respondents in that they are younger (only 21 percent of the high-involvement sample is 55 or older versus 26 percent for the non-highinvolvement category) and located in smaller to mid-size employers (33.9 percent of employees in high-involvement firms had 5,001 or more employees versus 39 percent of nonhigh-involvement firms). Interestingly, while the simultaneous presence of the three workplace systems (union x JCC x high-involvement) looks somewhat similar to the JCC category, education appears to differ. There is a larger proportion of respondents with a college/university degree (40.6) or post-graduate degree (10.6) amongst three-way respondents than in any of the other categories.

\section{Descriptive Evidence on Employee Satisfaction and Presence of Joint Consultation}

There is another way to reformulate the unconditional (raw) differences in employee satisfaction in relation to each key independent variable (i.e., presence of union recognition, JCC or high-involvement HR) and all two-way and the three-way interaction terms.

This is done in Table 4 which shows markedly higher satisfaction ratings amongst employees with access to a JCC (row 1) and high-involvement HR (row 3). The mean 
differences in overall workplace satisfaction found in column 5, between presence and nonpresence of JCCs and presence versus non-presence of high-involvement HR are large (0.7 and 1.7 respectively relative to a mean score of 4.36). These differences are also significantly positive. Union recognition displays the smallest difference (a negative -0.05 difference), which given the cross-sectional nature of our data, is perhaps not surprising since there is evidence in the literature that contextual factors related to unionised workplaces as well as 'selection' effects are likely at play in mediating the employee satisfaction ratings.

[Table 4]

Interestingly all three two-way interactions (rows 5 to 7 ) and the single three-way interaction term (row 8, where a respondent has a union, JCC and high-involvement HR at their workplace) display the highest employee satisfaction ratings, higher than the 'main effect' measures, with the largest differential occurring when JCCs are interacted in a threeway combination with HIHR and union (2.01 points greater). Union presence again does not appear to influence employee satisfaction (negatively or positively) in any of the two-way interactions.

This can be seen even more clearly in Figure 1, which plots the distribution of employee ratings for all three satisfaction measures in Panels a, b and c respectively, by presence of either a union, JCC, high-involvement HR or all three systems versus none. It is clear that having all three systems present at work is associated with a pronounced shift in the scores rightward (i.e., towards the maximum score of 7) with a rather thin tail of low scores (under 4) and a mass of responses at 5 and above. This is true of the high-involvement score distribution and for JCC presence as well. Union presence, on the other hand, is indistinguishable from the non-union and overall distribution of employee rating scores.

[Figure 1]

In sum, these descriptive statistics point to important "JCC" and "high-involvement HR" associations with respect to employee satisfaction, however measured. The latter --high- 
involvement $\mathrm{HR}$ - is associated with the highest employee satisfaction scores, followed by JCCs and a distant third being unions, which on balance is associated only slightly positively with job/work satisfaction and slightly negatively with managerial satisfaction. The unadjusted results also uncover a ‘non-relation' between union presence and our overall employee satisfaction measure. Coupled with evidence in Table 4 that the interaction between JCC and high-involvement HR (row 6) produces employee satisfaction scores larger than between union x JCC (row 5) or union x HIHR (row 7), this points to the potentially positive role being played by formal consultative voice systems and high-involvement managerial practices at work.

However, one should exercise caution as across the sample of employees being studied, there are some important differences in the nature of the workplaces (such as in size of establishment and industry etc.,) and sociodemographic characteristics (such as age, tenure and education etc.,) of respondents. So, the next step is to more formally 'test' our four hypotheses with empirical estimates of the union/joint consultation/high-involvement-related associations derived from statistical models that control for observed differences in employee and workplace characteristics.

\subsection{Empirical Models of Employee Satisfaction: A Test of Our Four Hypotheses}

Table 5 reports overall employee satisfaction rating differences between workplaces that have union recognition, joint consultative committee structures, and high-involvement human resource management practices and those that do not. These estimates condition on variables that are judged to be relevant predictors of employee satisfaction as well as typically hard-toobserve fixed 'attributes' of workers that may also play a role in selection to a union or having access to a non-union voice system. All of the control variables were described in section 3.2 above. Because of a lack of large differences in the qualitative and quantitative results amongst estimates using our two other dependent variables, we will concentrate on the 
'overall employee satisfaction' estimates found in Table 5 for the interpretation of our results and commentary on our four hypotheses, and allow readers to look at the results for the job and management satisfaction results in our Appendix A1 and A2 tables separately.

[Table 5]

Table 5 estimates of employee satisfaction differences related to union, JCC or highinvolvement presence are derived from two sets of specifications, the first set of four estimates (columns 1 to 4) show only the 'main effects' with increasingly numbers of righthand side controls added, and the second set (columns 5 to 8 ) is estimated with the full-set of two-way interaction terms and our single three-way interaction term, again with progressively more right-hand side controls added. The final column (8) represents the fully-specified model with all controls and all possible interactions added. All tables report OLS regression estimates of our dependent variable (i.e., our 1 to 7 scale measures of overall employee satisfaction) while our key independent measures are all dummy variables showing the rating differences among employees having union recognition, a JCC present or high-involvement HR versus those that do not.

\section{Hypothesis 1: Overall Employee Satisfaction and Union Recognition}

Table 5 shows that much like our unconditional results, there is no significant difference in overall employee satisfaction between union and non-union employees, conditional on having a JCC and a HIHR management approach in place. This is so in the first specification (column 1) which only controls for observed demographic characteristics such as age, gender, marital status, education, and immigrant status up to the last specification (column 4) which controls for workplace, industry and hard-to-observe personal attributes. In other words, the 'main effect' of unions in these cross-sectional specifications appears to be "zero", a finding in keeping with recent literature showing a tug of war between positive union "treatment" versus negative "selection and sorting" effects at the workplace (Laroche, 2016). But as 
these main-effect results are not significant, we consider this a weak confirmation of our first hypothesis.

\section{Hypothesis 2: Overall Employee Satisfaction and Joint Consultation Committees (JCCs)}

The unconditional results in Table 4 (column 5) and Figure 1 showed a positive difference of about 0.70 points - with respect to an average overall employee satisfaction score of 4.36 (or a 16 percent greater score) -- for employees having a joint consultative committee at work. When we examine Table 5, we see that the JCC relationship diminishes in magnitude to roughly a third of the unconditional value. Specifically, Table 5, column (4) yields an estimate of 0.242 . Though diminished in magnitude from the unconditional difference, the point estimate is robust across all the conditional models and highly significant (at the 1 percent level). So it seems that after controlling for union recognition and potentially substitutable high-involvement systems at work, the independent relationship between JCC presence and overall employee satisfaction (the 'main effect') is significant and remains so across all specifications (columns 1 to 4 ) that control for a host of right-hand side variables.

In columns 5 through 8 , where we add our interaction terms in addition to controlling for individual and workplace-related variables, the main effect of JCC presence does not diminish and in fact increases to 0.288 in the final fully interacted model estimate. We consider these estimates as a confirmation of Hypothesis 2.

Hypothesis 3: Overall Employee Satisfaction and High-Involvement Human Resource (HIHR) Management

The evidence of high-involvement HR and self-reported employee well-being was predicted to be positive, especially as we created a variable from our dataset that was meant to capture not just lukewarm but intense adoption of the high-involvement approach -- something noted in the literature as being highly relevant to the effectiveness of HR systems (see White and Bryson, 2013). The unconditional results in Table 4 and Figure 1 indicated that the largest 
differences, relative to unions and JCCs, resided between workers that had a highinvolvement HR system at work and those that did not. The difference was 1.71 points (Table 4 , column 5, row 3 ) on a mean score of 4.36 in overall employee satisfaction (or a 40 percent higher score from having high-involvement HR versus not).

The conditional estimates in Table 5 column 4 show that after controlling for simultaneous presence of a union and a JCC, as well a host of individual and workplace level controls, the relationship between high-involvement HR and overall employee satisfaction falls to 1.171 , a result that is still large and significant. The results are also highly significant and stable when the interaction terms are added (Table 5 in columns 5 to 8 ), i.e., the main effect coefficient rises to 1.265 (see Table 5, column 8), suggesting that like JCCs and union presence, the HIHR main effect is not being moderated by JCCs or unions in these data.

Hypothesis 4: Overall Employee Satisfaction and the Three-Way Interaction between JCC, HIHR and Unions

To test for our three-way interaction (treated here as the relationship between JCCs and our dependent variable, moderated by union and HIHR presence), we estimated a model that included all three independent variables, all three pairs of two-way interaction terms, and the three-way interaction term (see equation 2). The unconditional estimates in Table 4 showed a positive relationship when JCCs were interacted with HIHR and union presence (a difference in satisfaction score of 2.01 in Table 4, last row, column 5). This positive three-way interaction remains positive and significant in the regression analysis across columns 5 through 8 in Table 5, and thus we find evidence for "moderation" of the JCC relationship in these results.

Though Table 5 gave us the result that the association between JCC and overall employee satisfaction differs according to the presence of a union and HIHR, it is still not entirely clear how it differs. The positive coefficient of the interaction term suggests that it becomes more positive when a union and HIHR are present; however, the size and precise 
nature of this relationship is not easy to discern from examination of the coefficients alone, and becomes even more so when one or more of the dual interaction coefficients are negative, as is the case with the dual interaction term Union_X_HIHR (see Table 5, columns 5 to 8).

To overcome this and enable easier interpretation, we use a formulation proposed by Dawson (2014) to plot the three-way interaction relationship found in estimation (8) from Table 5, so we can interpret it visually. This is done by calculating predicted values of our dependent variable under different conditions (presence or non-presence of JCC, with presence or non-presence of a union and HIHR respectively) and showing the predicted relationship ("simple slopes") between JCC and overall employee satisfaction under the presence or lack thereof of union and HIHR.

The significance of the three-way interaction term (i.e., the coefficient $\beta$ in eq.2) determines whether the moderating effect of one variable (i.e.., HIHR) on the JCC-overall employee satisfaction relationship is itself moderated by (i.e., dependent on) the other moderator (i.e., union presence). Given that it is significant then the next challenge is to interpret the interaction. As mentioned, a useful starting point is to plot the effect. Figure 2 shows a plot of the situation described above, with the relationship between JCC presence and overall employee satisfaction moderated by both HIHR and union presence (Appendix Figures A1 and A2 do the same for our other two measures of employee satisfaction). The plot reveals a number of the relationships mentioned. For example, the association between JCCs and overall workplace satisfaction for unionised workers is "zero" when the individuals are working in a non-HIHR workplace (slope 2; black diamonds) or when a non-union worker is working in an HIHR workplace (slope 3; white squares). The relationship is somewhat larger for unionised workers who also have HIHR present at the workplace (slope 1; white diamonds), but the moderating relationship is greatest for those who have neither a union nor HIHR present at the workplace (slope 4; black squares).

[Figure 2] 
In other words, Figure 2 reveals that the possible synergies from having all three systems at work, as they relate to employee satisfaction, do appear salient. This is therefore a confirmation of our fourth hypothesis that the JCC relationship is positively moderated by the simultaneous presence of a union and high-involvement HR management.

\section{CONCLUSIONS}

Our paper has explored for the first time in a large-scale representative dataset, the relationship between JCCs in Britain and employee satisfaction. In particular, we focused on the relationship between JCCs and employee well-being whilst controlling for highinvolvement HR practices and union presence, which though in decline since the 1980s is still found in roughly one in ten of all workplaces in Britain (with 5 employees or more) and covering roughly one third of all workers. We examined JCCs as direct contributors to employee well-being and the potential interactions with existing union representation and high-involvement HR management.

The findings reveal two important facts: i) a revaluation of the relevance and role that JCCs play as a workplace institution in Britain, given that JCCs are associated positively with the subjective wellbeing of workers, and ii) the potential 'independently positive' role that high-commitment HR policies play in fostering satisfaction and wellbeing at work.

Given that the main effects of JCCs and high-involvement HR remain significant in every one of our estimates and rise in magnitude with the addition of controls and our interaction terms, there is no evidence of full mediation (i.e., that non-union voice in the form of JCCs substitutes for unions or is a proxy for more inclusive HR policies) at work. There is a threeway interaction effect (i.e., JCC association with respect to overall employee satisfaction is higher in the presence of HIHR and unions at the workplace) but this three-way effect does not wipe out the main effects of JCC or HIHR, suggesting that union presence, JCC and HIHR management can exist side by side without compromising employee well-being and in 
the former two cases, have large independent associations that require further exploration.

Having demonstrated a positive employee satisfaction link using the SWERS data, examining the determinants of JCCs and other workplace institutions would be the next avenue of research to pursue. 


\section{REFERENCES}

Abowd, J. M., \& Farber, H. S. (1982). Job queues and the union status of workers. ILR Review, 35(3), 354-367.

Adam, Duncan, John Purcell and Mark Hall (2014). "Joint consultative committees under the Information and Consultation of Employees Regulations: A WERS analysis". Ref 04/14 ACAS Research Paper.

Addison, J.T. (2009). The Economics of Codetermination: Lessons from the German Experience. New York: Palgrave Macmillan

Addison, J. T., Bryson, A., Teixeira, P., Pahnke, A., \& Bellmann, L. (2013). “The extent of collective bargaining and workplace representation: transitions between states and their determinants. A comparative analysis of Germany and Great Britain." Scottish Journal of Political Economy, 60(2), 182-209

Appelbaum E, Bailey T and Berg P (2000) Manufacturing Advantage: Why High Performance Work Systems Pay off. Ithaca, NY: Cornell University Press.

Aradanaz-Badia A, Awano G and Wales P (2017) Understanding firms in the bottom 10\% of the labour productivity distribution in Great Britain: "the laggards", 2003 to 2015, London: Office for National Statistics.

Artz, B. (2010). The impact of union experience on job satisfaction. Industrial Relations: A Journal of Economy and Society, 49(3), 387-405.

Askenazy P and Forth J (2016) "Work organisation and human resource management: does context matter?", pp.141-178 in Amossé T, Bryson A, Forth J and Petit H (eds.) Comparative Workplace Employment Relations: An Analysis of Britain and France, Basingstoke: Palgrave Macmillan.

Barth, Erling; Alex Bryson, James C. Davis, Richard Freeman. (2016). "It's Where You Work: Increases in Earnings Dispersion across Establishments and Individuals in the U.S." Journal of Labor Economics, 34: S2, Part 2.

Batstone, E., Ferner, A. and Terry, M. (1983) "Unions on the Board", Employee Relations, Vol. 5 Issue: 5, pp.2-4

Black S and Lynch L (2001) "How to compete: the impact of workplace practices and information technology on productivity", Review of Economics and Statistics, 83(3): 434445.

Blasi, Joseph, Richard Freeman and Douglas Kruse. (2015). "Do Broad-based Employee Ownership, Profit Sharing and Stock Options Help the Best Firms Do Even Better?" British Journal of Industrial Relations, 54(1): pp 55-82 (doi: 10.1111/bjir.12135)

Bloom, Nicholas, and John Van Reenen. 2010. "Why Do Management Practices Differ across Firms and Countries?" Journal of Economic Perspectives, 24 (1): 203-24.

Bloom, N., Sadun, R., \& Van Reenen, J. (2016). Management as a Technology? (No. w22327). National Bureau of Economic Research. 
Bloom N, Lemos R, Qi M, Sadun R and Van Reenen J (2011) "Constraints on developing UK management practices", BIS Research Paper No. 58, London: Department for Business Innovation and Skills.

Bloom N, Genakos C, Sadaun R and Van Reenen J (2012) "Management practices across firms and countries", NBER Working Paper No. 17850.

Bloom N, Lemos R, Sadun R, Scur D and Van Reenen J (2014) "The new empirical economics of management”, Occasional Paper No. 41, London: Centre for Economic Performance.

Bloom N, Sadun R and Van Reenen J (2016a) "Management as technology”, CEP Discussion Paper No. 1433, London: Centre for Economic Performance.

Bloom N, Lemos R, Sadun R, Scur D and Van Reenen J (2016b) "International data on measuring management practices”, American Economic Review, 106:5, pp.152-156.

Bloom N, Brynjolfsson E, Foster L, Jarmin R, Patnaik M, Saporta-Eksten I and Van Reenen J (2017) "What drives differences in management?", CEP Discussion Paper No. 1470, London: Centre for Economic Performance.

Böckerman, P., Bryson, A., and Ilmakunnas, P. (2012). "Does high involvement management improve worker wellbeing?" Journal of Economic Behavior \& Organization, 84(2), 660680 .

Böckerman, P., and Ilmakunnas, P. (2012). The job satisfaction-productivity nexus: A study using matched survey and register data. ILR Review, 65(2), 244-262.

Booth, Alison L. (1985). "The free rider problem and a social custom model of trade union membership" The Quarterly Journal of Economics, 100:1, pp. 253-261.

Booth, Alison L. (1995). The economics of the trade union. Cambridge: Cambridge University Press.

Borjas, G. J. (1979). Job satisfaction, wages, and unions. Journal of Human Resources, Vol. 14, No. $121-40$.

Bresnahan, Timothy F.; Erik Brynjolfsson, Lorin M. Hitt; "Information Technology, Workplace Organization, and the Demand for Skilled Labor: Firm-Level Evidence," The Quarterly Journal of Economics, Volume 117, Issue 1, 1 February 2002, Pages 339-376, https://doi.org/10.1162/003355302753399526

Brewster, C, G. Wood, R. Croucher, and M. Brookes. (2007). “Are Works Councils and Joint Consulative Committees a Threat to Trade Unions? A Comparative Analysis". Economic and Industrial Democracy, Vol. 28(1): 49-77.

Broszeit S, Fritsch U, Görg H and Marie-Christine Liable (2016) "Management practices and productivity in Germany”, IAB Discussion Paper No. 32/2016, Nuremberg: Institute for Employment Research. 
Brynjolfsson E and McElheran K (2016a) "Data in action: data-driven management in US manufacturing”, CES Working Paper 16-06, Washington DC: Centre for Economic Studies.

Brynjolfsson E and McElheran K (2016b) "The rapid adoption of data-driven decision making”, American Economic Review: Papers and Proceedings, 106, 5: 133-139.

Bryson, Alex, (2017). "Mutual Gains? Is There a Role for Employee Engagement in the Modern Workplace?". IZA Discussion Paper No. 11112. Available at SSRN: https://ssrn.com/abstract $=3069455$

Bryson, A. , Cappellari, L. and Lucifora, C. (2010), "Why So Unhappy? The Effects of Unionization on Job Satisfaction." Oxford Bulletin of Economics and Statistics, 72: 357380. doi:10.1111/j.1468-0084.2010.00587.x

Bryson, A. and Freeman, R. B. (2013) 'Employee Perceptions of Working Conditions and the Desire for Worker Representation in Britain and the US', Journal of Labor Research, 34, 1: $1-29$

Bryson, Alex and Michael White, (2016a). "Not so dissatisfied after all? The impact of union coverage on job satisfaction”, Oxford Economic Papers, 68, 4, (898), (2016).

Bryson, Alex and Michael White, (2016b). "Unions and the economic basis of attitudes," Industrial Relations Journal, 47, 4, (360-378).

Bryson, A., Forth, J., and Stokes, L. (2017). "Does employees' subjective well-being affect workplace performance?” Human Relations, 70(8), 1017-1037.

Bryson, A., L Cappellari, and C Lucifora. (2004). "Does union membership really reduce job satisfaction?" British Journal of Industrial Relations 42 (3), 439-459

Bryson, Alex, Andy Charlwood, and John Forth. (2006) "Worker voice, managerial response and labour productivity: an empirical investigation." Industrial Relations Journal 37.5 (2006): 438-455.

Bryson, A., Willman, P., Gomez, R., and Kretschmer, T. (2013). The Comparative Advantage of Non-Union Voice in Britain, 1980-2004. Industrial Relations: A Journal of Economy and Society, 52, 194-220.

Bryson, Alex; Richard B. Freeman, Rafael Gomez, and Paul Willman (2017). "The Twin Track Model of Employee Voice: An Anglo-American Perspective on Union Decline and the Rise of Alternative Forms of Voice" IZA Discussion Paper No. 11223

Cascio, W. F. (2015). Strategic HRM: Too important for an insular approach. Human Resource Management, 54(3), 423-426.

Christian, M. S., Garza, A. S., \& Slaughter, J. E. (2011). Work engagement: A quantitative review and test of its relations with task and contextual performance. Personnel psychology, 64(1), 89-136. 
Danford, Andy; Michael Richardson,Paul Stewart and Stephanie Tailby, and Martin Upchurch. (2005). "Workplace Partnership and Employee Voice in the UK: Comparative Case Studies of Union Strategy and Worker Experience" Economic and Industrial Democracy. Vol. 26(4): 593-620.

Dawson, J. F., \& Richter, A. W. (2006). "Probing three-way interactions in moderated multiple regression: Development and application of a slope difference test." Journal of Applied Psychology, 91, 917-926.

Dawson, J. F. (2014). "Moderation in management research: What, why, when and how." Journal of Business and Psychology, 29, 1-19.

Dobbins A and Gunnigle P (2009) "Can voluntary workplace partnership deliver sustainable mutual gains?” British Journal of Industrial Relations. 47(3): 546-570.

Dodge, Y. 2006. The Oxford Dictionary of Statistical Terms. $6^{\text {th }}$ edition. Oxford: Oxford University Press.

Freeman, R. B. "Job Satisfaction As An Economic Variable," American Economic Review, 1978, v68(2), 135-141

Frege, C. (2005). The discourse of industrial democracy: Germany and the US revisited. Economic and Industrial Democracy, 26(1), 151-175.

Frege, C. (2002) 'Theoretical and Empirical Research on German Works Councils: A Critical Assessment', British Journal of Industrial Relations 40(2): 221-48.

Freeman, R. B. and Pelletier, J. (1990) "The impact of industrial relations legislation on British union density", British Journal of Industrial Relations, 28, 2: 141-164

Frick, B. and Simmons, R. (2008), "The impact of managerial quality on organizational performance: evidence from German soccer.” Manage. Decis. Econ., 29: 593-600. doi:10.1002/mde.1431

Forth, John, and Robert McNabb. (2008) "Workplace performance: a comparison of subjective and objective measures in the 2004 Workplace Employment Relations Survey." Industrial Relations Journal 39.2 (2008): 104-123.

Forth, John; Alex Bryson and Anitha George. (2017) "Explaining Cross-National Variation in Workplace Employee Representation" European Journal of Industrial Relations, 23 (4), 415-43.

Fried, Y., \& Ferris, G. R. (1987). "The validity of the job characteristics model: A review and meta-analysis." Personnel psychology, 40(2), 287-322.

Godard J (2004) "A critical assessment of the high-performance paradigm.” British Journal of Industrial Relations 42(2): 349-378.

Godard, J. (2007). Unions, work practices, and wages under different institutional environments: The case of Canada and England. ILR Review, 60(4), 457-476. 
Gollan, P. J., Kaufman, B. E., Taras, D. \& Wilkinson, A. (Eds.). (2015). Voice and involvement at work: Experience with non-union representation. Oxford: Routledge.

Gospel, H., \& Willman, P. (2003). High performance workplaces: The role of employee involvement in a modern economy evidence on the EU directive establishing a general framework for informing and consulting employees. Centre for Economic Performance, London School of Economics and Political Science.

Green, C. and Heywood, J. S. (2015). 'Dissatisfied union workers: sorting revisited'. British Journal of Industrial Relations, 53 (3): 580-600.

Green,F. and K.Whitfield (2009), “Employees' experience of work”, in Whitfield,K. etal. (eds.), The evolution of the modern workplace, Cambridge University Press, Cambridge

Grund, Christian, Alex Bryson, Robert Dur, Christine Harbring, Alexander K. Koch, and Edward P. Lazear. (2017) "Personnel economics: A research field comes of age" German Journal of Human Resource Management. Vol 31, Issue 2, pp. 101 - 107

Guest, D., and Conway, N. (1999). "Peering into the black hole: the downside of the new employment relations in the UK." British Journal of Industrial Relations, 37(3), 367-389.

Guest D and Peccei R (2001) "Partnership at work: Mutuality and the balance of advantage." British Journal of Industrial Relations 39(2): 207-236.

Hackman, J. R., \& Oldham, G. R. (1976). Motivation through the design of work: Test of a theory. Organizational behavior and human performance, 16(2), 250-279.

Hipp, Lena and Rebecca Kolins Givan, (2015) "What Do Unions Do? A Cross-National Reexamination of the Relationship between Unionization and Job Satisfaction", Social Forces, 94, 1, (349).

Ichniowski, C., Shaw, K. and Prennushi, G. (1997) "The effects of human resource management practices on productivity: A study of steel finishing lines." The American Economic Review, 87, 3: 291-313.

Johnson, E.L (1952). “Joint Consultation in Britain's Nationalized Industries.” Public Administration Review, 12(3), 181-189.

Joyce, P and A Woods. (1984). "Joint Consultation in Britain: Towards an Explanation". Employee Relations, Vol. 6(2): 2-8.

Kaufman, B. E. (2012). "Strategic human resource management research in the United States: A failing grade after 30 years?." Academy of Management Perspectives, 26(2), 12-36.

Kaufman, B. E. (2015a). Market competition, HRM, and firm performance: The conventional paradigm critiqued and reformulated. Human Resource Management Review, 25(1), 107125.

Kaufman, B. E. (2015b). Evolution of strategic HRM as seen through two founding books: A 30 th anniversary perspective on development of the field. Human Resource Management, 54(3), 389-407. 
Kaufman, Bruce E. (2017). "Great in Theory but Tough in Practice:Insights on Sustaining Advanced Employee Involvement at Delta Air Lines" In Advances in Industrial and Labor Relations, 2017: Shifts in Workplace Voice, Justice, Negotiation and Conflict Resolution in Contemporary Workplaces; pp. 57-89.

Keller, Berndt and Sabrina Weber. (2011). "Sectoral social dialogue at EU level: Problems and prospects of implementation." European Journal of Industrial Relations. Vol 17, Issue 3 , pp. $227-243$

Kochan, T. A McKersie, R. B. and Cappelli, P. (1984), Strategic Choice and Industrial Relations Theory. Industrial Relations: A Journal of Economy and Society, 23: 16-39. doi:10.1111/j.1468-232X.1984.tb00872.

Kruse, D., Freeman, R. and Blasi, J. (2010) Shared Capitalism at Work: Employee Ownership, Profit and Gain Sharing, and Broad-based Stock Options, University of Chicago Press.

Blasi, J. R., Freeman, R. B., \& Kruse, D. L. (2015). “Capitalism for the rest of us.” New York Times A, 19.

Laroche, Patrice (2016). "A Meta-Analysis of the Union-Job Satisfaction Relationship", British Journal of Industrial Relations, 54, 4, (709-741).

Laroche, Patrice (2017). "Union membership and job satisfaction: Initial evidence from French linked employer-employee data," Human Resource Management Journal, 27, 4, (648-668)

Lazear E (2000) "Performance pay and productivity", American Economic Review, 90(5), pp.1346-1361.

Machin, S., \& Wood, S. (2005). "Human Resource Management as a Substitute for Trade Unions in British Workplaces." Industrial and Labor Relations Review, 58(2), 201-218

Milner, S. (1995). The coverage of collective pay-setting institutions in Britain, 1895-1990. British Journal of Industrial Relations, 33(1), 69-91.

Morgeson, F. P., \& Humphrey, S. E. (2006). The Work Design Questionnaire (WDQ): developing and validating a comprehensive measure for assessing job design and the nature of work. Journal of applied psychology, 91(6), 1321.

O'Connor, S. (2017). "Taylor Report to Call for More "Voice" for UK Workers". Financial Times, July 7, 2017. Downloaded at: https://wwww.ft.come/content/422b3c9a-6248-11e7$\underline{91 \mathrm{a} 7-502 \mathrm{f} 7 \mathrm{ee} 26895}$

Oswald, A. J., Proto, E., \& Sgroi, D. (2015). "Happiness and productivity." Journal of Labor Economics, 33(4), 789-822.

Parker, Sharon and Toby Wall (1998). Job and Work Design: Organizing Work to Promote Well-Being and Effectiveness. New York: Sage Publications. http://dx.doi.org/10.4135/9781452231518.n5 
Pfeffer, J. (2018). Dying for a Paycheck:: How Modern Management Harms Employee Health and Company Performance - and What We Can Do About It. New York: HarperCollins.

Pfeffer, J., \& Davis-Blake, A. (1990). Unions and job satisfaction: an alternative view. Work and Occupations, 17(3), 259-283.

Pohler, D. M., \& Luchak, A. A. (2014). "Balancing efficiency, equity, and voice: The impact of unions and high-involvement work practices on work outcomes." ILR Review, 67(4), 1063-1094.

Poole, M, (1986) Towards a New Industrial Democracy. London: Routledge.

Poole, M. (1989). The Origins of Economic Democracy. London: Routledge.

Ramsay H, Scholarios D and Harley B (2000) "Employees and high-performance work systems: Testing inside the black box." British Journal of Industrial Relations 38(4): 501531.

Saridakis, George; Yanqing Lai, and Stewart Johnstone (2017). "Does workplace partnership deliver mutual gains at work?" Economic and Industrial Democracy. Published online December 5, 2017. https://doi.org/10.1177/0143831X17740431

Taras, D. G., \& Kaufman, B. E. (2006). "Non-union employee representation in North America: diversity, controversy and uncertain future". Industrial Relations Journal, 37(5), 513-542.

Traxler,F. (1995), "Farewell to labour market associations? Organized versus disorganized decentralization as a map for industrial relations", in Crouch,C. and F.Tr axler (eds.),Organized industrial relations in Europe: What future?, Aldershot, Avebury.

Traxler,F., S.Blaschke and B.Kittel (2001), National labour relations in internationalized markets, Oxford University Press, Oxford.

Teulings, C.N. and J. Hartog (1998). Corporatism or competition? Labour contracts, institutions and wage structures in international comparison. Cambridge University Press, Cambridge.

UKPOL (2016). “Theresa May - 2016 Speech to Launch Leadership Campaign”. Downloaded from: http://www.ukpol.co.uk/theresa-may-2016-speech-to-launchleadership-campaign/

Walton, R.E. (1985). "From Control to Commitment in the Workplace", Harvard Business Review, 63(2): 77-84

Webb, S. and B. Webb (1897) Industrial Democracy. London: Longmans, Green \& Co.

Wheelwright, E. L. (1954)," Joint Consultation in Britain". Australian Journal of Public Administration, 13: 236-250. doi:10.1111/j.1467-8500.1954.tb01698.x

Willman, P., Bryson, A., and Gomez, R. (2006). "The sound of silence: which employers choose no employee voice and why?" Socio-Economic Review, 4(2), 283-299. 
Wilkinson A, Dundon T, Donaghey J and Townsend K (2014). "Partnership, collaboration and mutual gains: Evaluating context, interest and legitimacy." International Journal of Human Resource Management 25(6): 737-747.

Wilkinson, Adrian, Michael Barry, Rafael Gomez, and Bruce E Kaufman. (2018a). "Taking the pulse at work: An employment relations scorecard for Australia", Journal of Industrial Relations. Vol 60, Issue 2, pp. $145-175$.

Wilkinson, Adrian, Paul J. Gollan, Senia Kalfa and Ying Xu. (2018b). "Voices unheard: employee voice in the new century". The International Journal of Human Resource Management. Volume 29, 2018 - Issue 5, pp. 711-724.

Wu N, Bacon N and Hoque K (2014) "The adoption of high performance work practices in small businesses: the influence of markets, business characteristics and HR expertise", The International Journal of Human Resource Management, 25, 8: 1149-1169.

Wu, N., Hoque, K., Bacon, N., Llusar, B. and Carlos, J. (2015) "High-performance work systems and workplace performance in small, medium-sized and large firms", Human Resource Management Journal, 25(4), pp.408-423.

Figure 1: Distribution of Employee Satisfaction Scores By Workplace Representation and Presence of High-involvement Human Resource Management.

Panel a) Employee Satisfaction Ratings of Job and Work (1 to 7 low-to-high Scale) 


\section{Worker Attitudes Towards Job}

Union

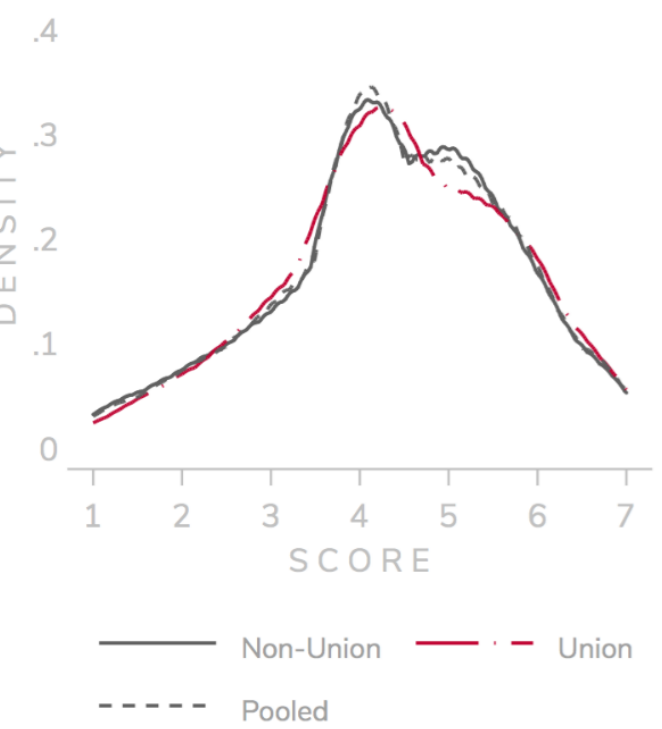

HIHR

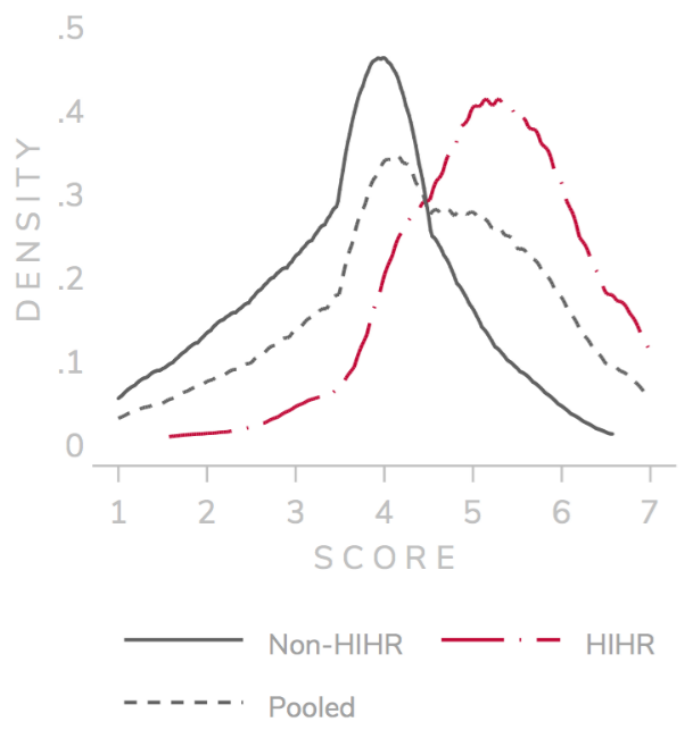

Committee

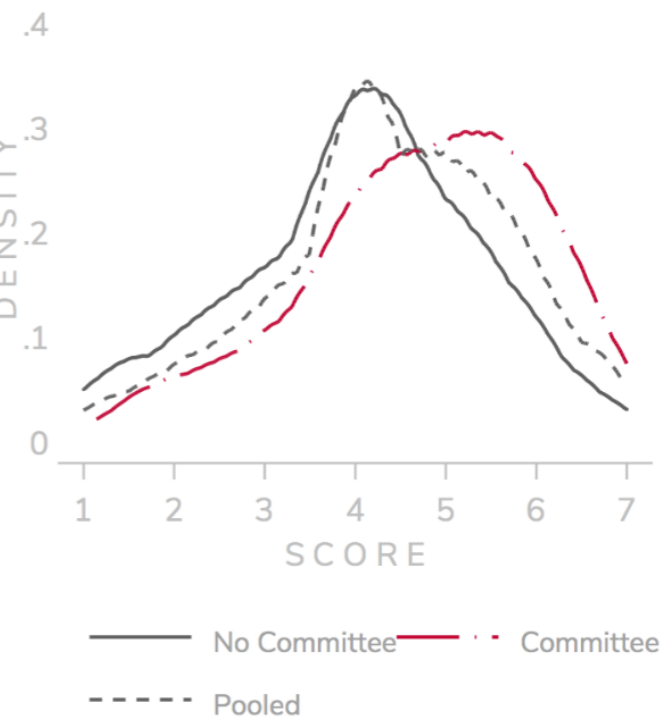

All

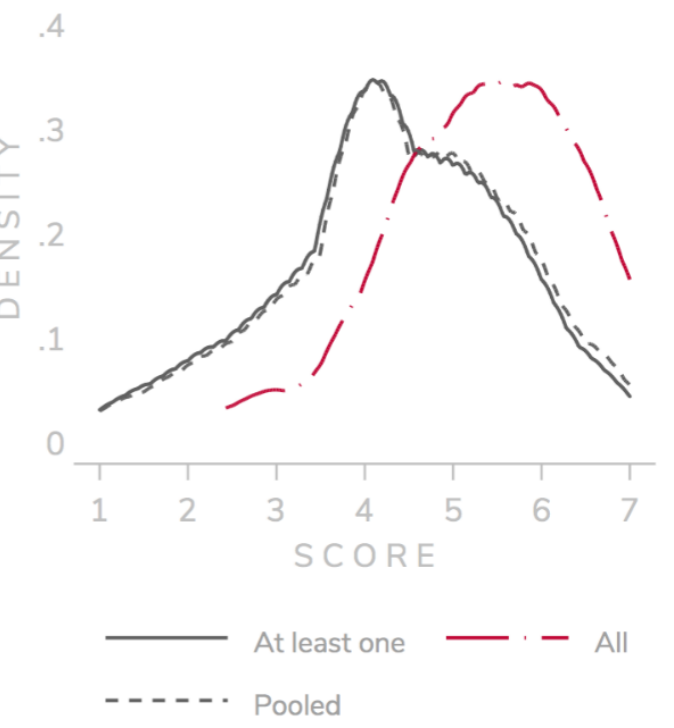

Panel b) Employee Satisfaction Ratings of Management (1 to 7 low-to-high Scale) 


\section{Worker Attitudes Towards Managers}

Union

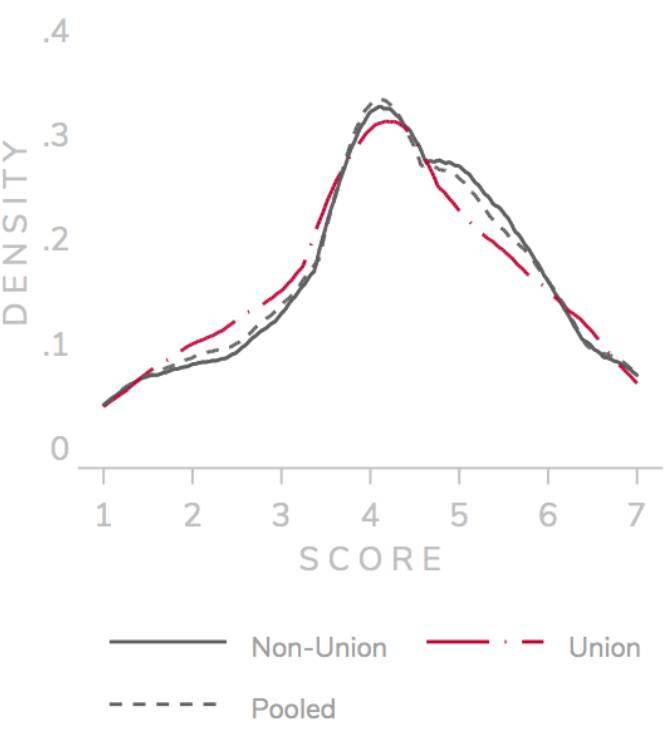

HIHR

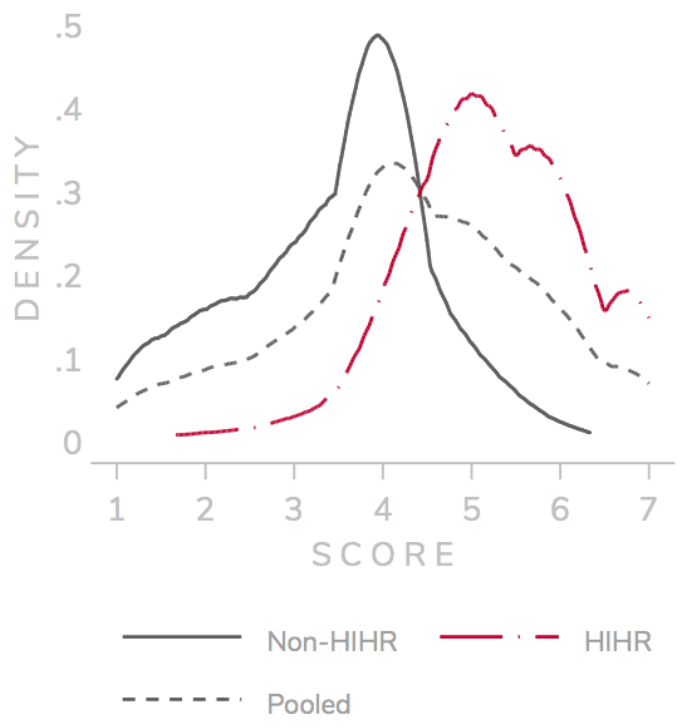

Committee



All

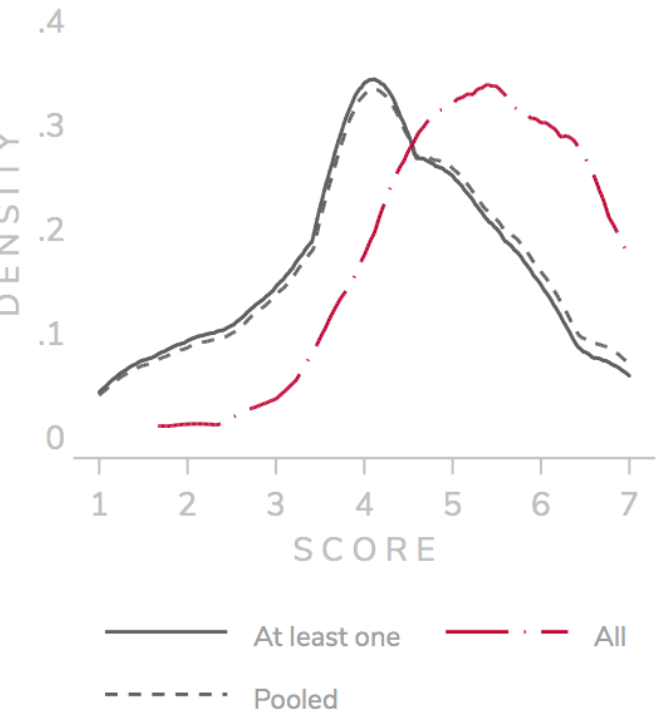

Panel c) Employee Satisfaction Ratings of Workplace Overall (1 to 7 low-to-high Scale) 


\section{Overall Attitudinal Score}

Union

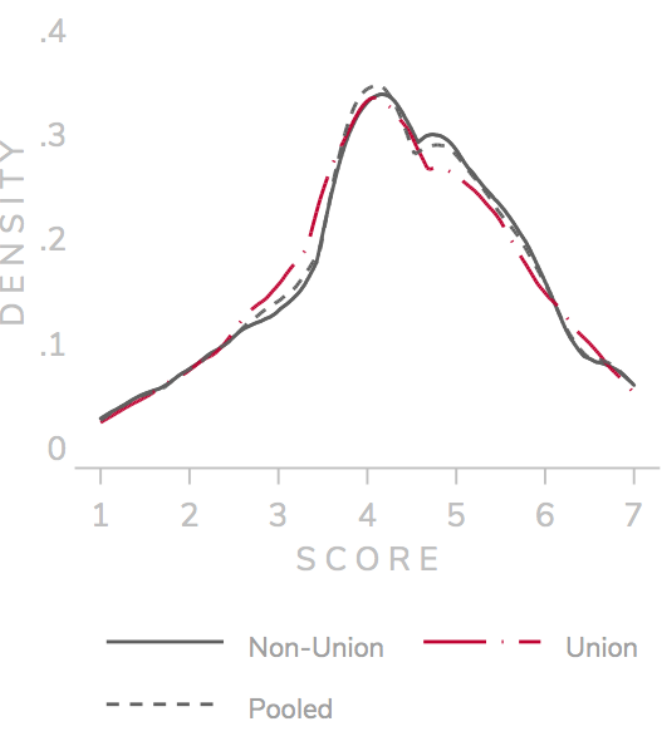

HIHR

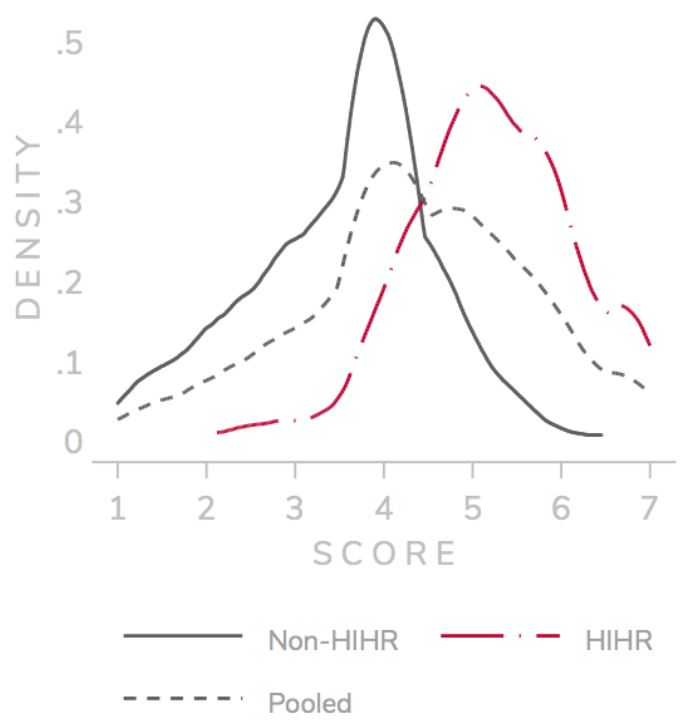

Committee

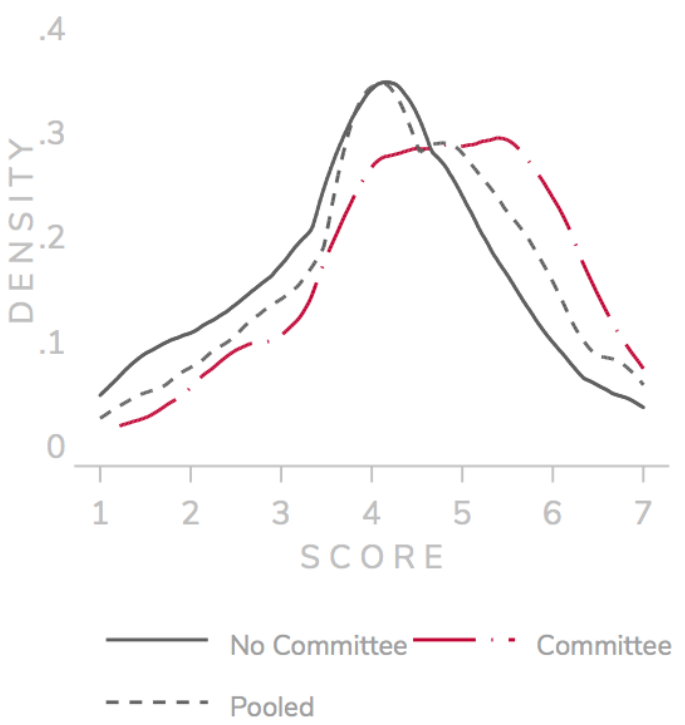

All

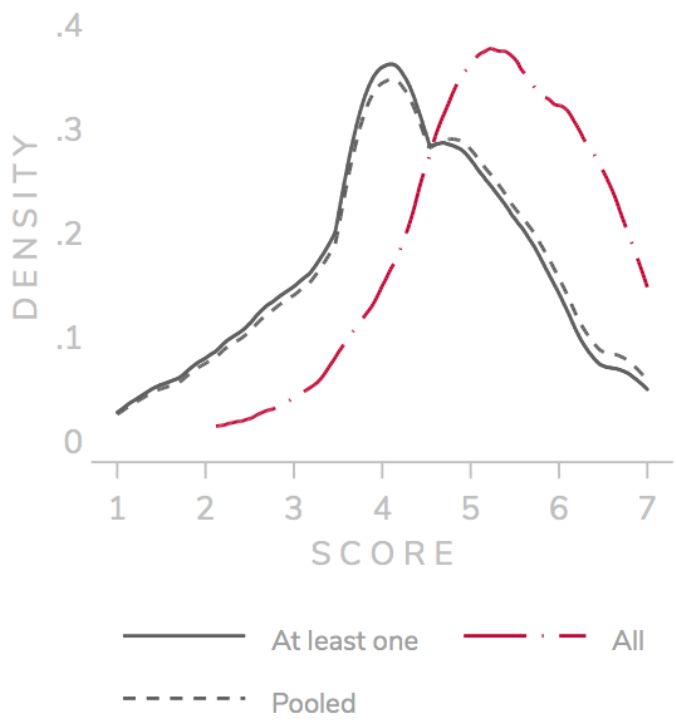

Figure 2: Moderating relationship of HIHR and Union presence on the JCC-overall employee satisfaction relationship (three-way interaction with binary moderators) 


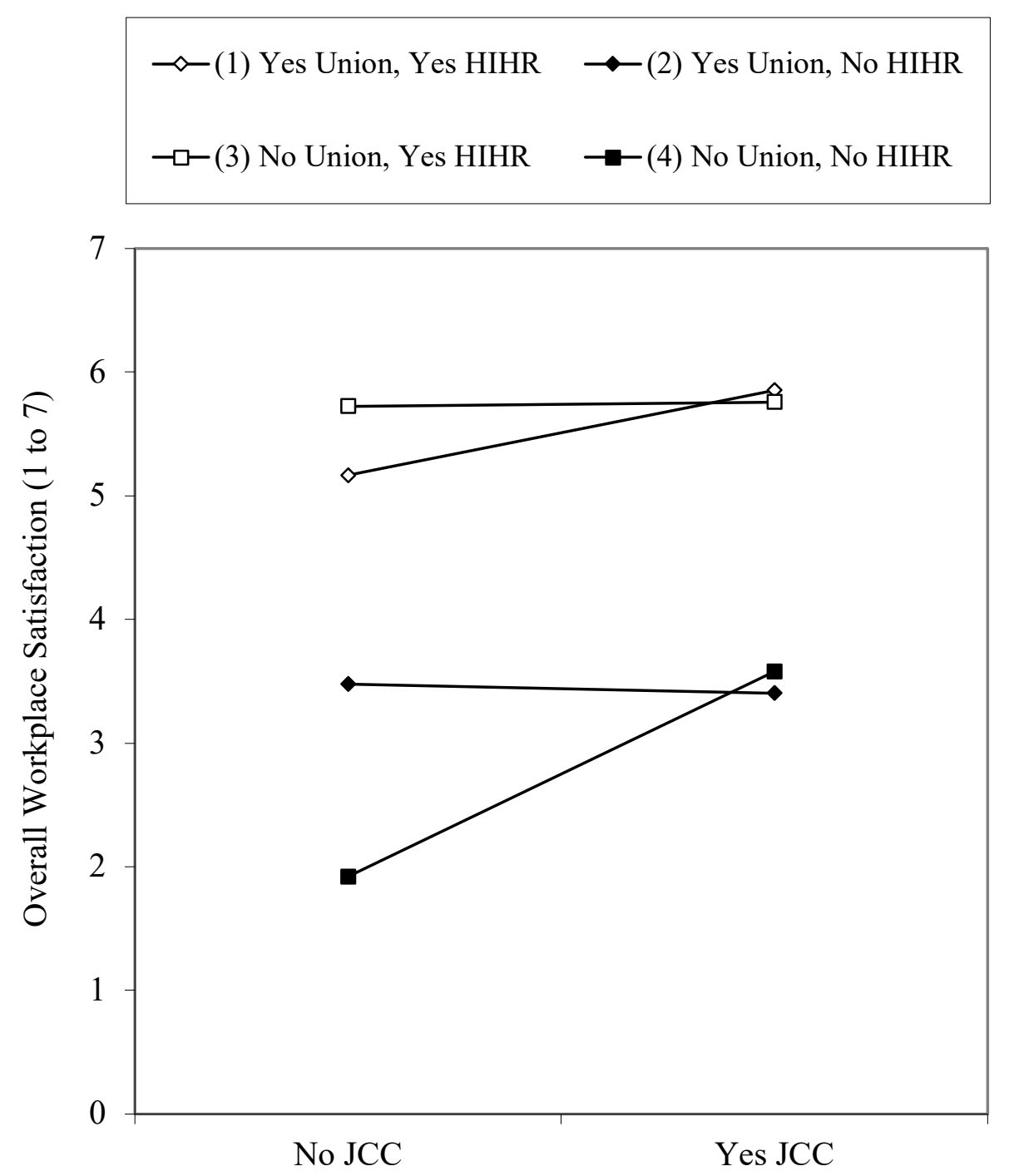

Table 1: Results of Factor Analysis for Employee Satisfaction Questions

Dependent Variable SWERS Survey Questions


Satisfaction with managers/management (9 items)

$($ Cronbach alpha $=0.92)$

Satisfaction with

job/work

(7 items)

$($ Cronbach alpha $=0.93)$

Overall Employee

Satisfaction

(16 items)

(Cronbach alpha $=0.82)$
- Managers I am familiar with do a great job of getting employees enthusiastic and engaged in their jobs.

- Managers I am familiar with do a great job in getting employees knowledgeable about, focused on, and working toward the company/organization's goals and objectives.

- Managers I am familiar with are great at empowering and trusting employees to get their jobs done with minimum necessary oversight and direction.

- Great relations between management and employees.

- Great employee morale.

- The person I work for/report to is a great manager.

- Overall, my unit/workplace has a great performing 'first class' leadership-management team.

- Overall, the employees at my unit/workplace are a great performing 'first class' team of workers.

- Managers I am familiar with do a great job of treating employees fairly, humanely, and respectfully.

- All things considered, my unit/workplace is a great place to work.

- All things considered, I have a great job.

- I am strongly attached to my current unit/workplace, such that it would take a very attractive job offer to get me to leave.

- When I compare everything I get with everything I give, I have a great deal as an employee.

- My unit/workplace provides great pay for a person with my qualifications.

- My unit/workplace provides great benefits for a person with my qualifications.

- Overall, I feel very satisfied with my current job/employment situation.

Source: State of Workplace Employment Relations Survey (SEWRS), 2016.

Table 2: Measures of High Involvement HR Management (HIHRM)

Independent Variable SWERS Survey Questions 
High-involvement HRM

(Cronbach alpha $=0.89$ )
- Involvement in way work gets done: Management is great at providing employees with voice and involvement in the way work gets done.

- Employee feedback methods: There is extensive use of employee listening and opinion methods, such as surveys, focus groups, and Q\&A sessions, to find out employees' satisfactions and dissatisfactions.

- Internal dispute process: For jobs like mine, work-related disputes between employees and managers go through a formal process that is fair, impartial, and without fear of retaliation.

- Information on company decisions: My unit/workplace is great at internal communication with employees so we have full and accurate information on decisions and developments that affect us.

- Management by commitment over control: Generally speaking, do managers at your unit/workplace use a Command-Control style where they make the decisions and pass down the orders to the employees to execute, or a Collaborative-Commitment style where they consult employees on decisions and trust the employees will execute them if given opportunity for self-direction, or some combination of the two?

- 'Carrot' versus 'stick' managerial approach: Generally speaking, do managers at your unit/workplace use fear of negative consequences (the 'Stick') to get employees to do what they want or hope of positive rewards (the 'Carrot'), or some combination of the two?

Source: State of Workplace Employment Relations Survey (SEWRS), 2016. 
Table 3: Sample Characteristics By Type of Workplace Representation and HR system Among Employees in Britain, 2016

\begin{tabular}{|c|c|c|c|c|c|c|c|c|c|}
\hline \multirow[t]{3}{*}{ Presence at the Workplace of: } & \multicolumn{2}{|c|}{$\begin{array}{c}\text { Union } \\
\text { Representation }\end{array}$} & \multicolumn{2}{|c|}{$\begin{array}{l}\text { Joint Consultative } \\
\text { Committee }\end{array}$} & \multicolumn{2}{|c|}{$\begin{array}{c}\text { High Involvement } \\
\text { HRM }\end{array}$} & \multicolumn{2}{|c|}{$\begin{array}{l}\text { Union x JCC x } \\
\text { HIHR }\end{array}$} & Full Sample \\
\hline & \multicolumn{2}{|c|}{$[1]$} & \multicolumn{2}{|c|}{$[2]$} & \multicolumn{2}{|c|}{ [3] } & \multicolumn{2}{|c|}{ [4] } & {$[5]$} \\
\hline & No & Yes & No & Yes & No & Yes & No & Yes & All \\
\hline \multicolumn{10}{|l|}{ Dependent Variables (1 - 7 Scale) } \\
\hline Satisfaction with Job / Work & 4.391 & 4.417 & 4.048 & 4.731 & 3.632 & 5.207 & 3.392 & 5.348 & 4.399 \\
\hline Satisfaction with Management & 4.362 & 4.249 & 3.963 & 4.672 & 3.428 & 5.266 & 3.294 & 5.347 & 4.323 \\
\hline Overall Workplace Satisfaction & 4.376 & 4.333 & 4.006 & 4.701 & 3.530 & 5.236 & 3.343 & 5.348 & 4.361 \\
\hline \multicolumn{10}{|l|}{ Independent Variables } \\
\hline \multicolumn{10}{|l|}{ Gender } \\
\hline Female & 0.488 & 0.485 & 0.468 & 0.475 & 0.470 & 0.506 & 0.423 & 0.438 & 0.487 \\
\hline Male & 0.512 & 0.515 & 0.532 & 0.525 & 0.530 & 0.494 & 0.577 & 0.562 & 0.513 \\
\hline \multicolumn{10}{|l|}{ Age } \\
\hline $18-24$ & 0.081 & 0.043 & 0.058 & 0.072 & 0.049 & 0.087 & 0.057 & 0.088 & 0.068 \\
\hline $25-34$ & 0.189 & 0.142 & 0.181 & 0.143 & 0.151 & 0.195 & 0.171 & 0.162 & 0.173 \\
\hline $35-44$ & 0.274 & 0.213 & 0.262 & 0.241 & 0.251 & 0.256 & 0.281 & 0.212 & 0.253 \\
\hline $45-54$ & 0.245 & 0.313 & 0.248 & 0.278 & 0.283 & 0.252 & 0.243 & 0.262 & 0.268 \\
\hline $55+$ & 0.212 & 0.289 & 0.252 & 0.267 & 0.266 & 0.209 & 0.249 & 0.275 & 0.238 \\
\hline \multicolumn{10}{|l|}{ Marital Status } \\
\hline Married /Living with partner & 0.592 & 0.651 & 0.623 & 0.624 & 0.591 & 0.635 & 0.589 & 0.706 & 0.612 \\
\hline Divorced / separated & 0.101 & 0.092 & 0.096 & 0.095 & 0.101 & 0.094 & 0.114 & 0.088 & 0.098 \\
\hline Single / Never Married & 0.299 & 0.237 & 0.265 & 0.267 & 0.294 & 0.261 & 0.289 & 0.201 & 0.278 \\
\hline Widowed & 0.007 & 0.021 & 0.016 & 0.012 & 0.013 & 0.009 & 0.009 & 0.006 & 0.011 \\
\hline \multicolumn{10}{|l|}{ Education } \\
\hline GCSE or equivalent & 0.276 & 0.263 & 0.299 & 0.233 & 0.285 & 0.257 & 0.294 & 0.212 & 0.272 \\
\hline A-level or equivalent & 0.259 & 0.207 & 0.224 & 0.265 & 0.227 & 0.256 & 0.223 & 0.251 & 0.241 \\
\hline
\end{tabular}


College degree or equivalent

Postgraduate degree or equivalent

Immigrant

Non-Immigrant

Immigrant

Race

White

Non-White

Occupation

Lower Management

White-Collar

Blue-Collar

Service Level

b. Workplace-Related Characteristics

Tenure at workplace

Less than 1 year

1 - 2 years

3 - 4 years

5 - 9 years

10 - 14 years

15 - 19 years

20 years or longer

Size of Organization

21 - 50 employees

51 - 100 employees

101 - 500 employees

501 - 1,000 employees

1,001 - 5,000 employees

5,001 employees or more

$\begin{array}{lllllllll}0.353 & 0.368 & 0.349 & 0.374 & 0.365 & 0.350 & 0.357 & 0.406 & 0.358 \\ 0.085 & 0.137 & 0.099 & 0.101 & 0.092 & 0.114 & 0.091 & 0.106 & 0.103\end{array}$

$\begin{array}{lllllllll}0.914 & 0.943 & 0.935 & 0.914 & 0.931 & 0.918 & 0.926 & 0.906 & 0.924 \\ 0.084 & 0.057 & 0.064 & 0.086 & 0.069 & 0.081 & 0.071 & 0.094 & 0.075\end{array}$

$\begin{array}{lllllllll}0.084 & 0.057 & 0.064 & 0.086 & 0.069 & 0.081 & 0.071 & 0.094 & 0.075\end{array}$

$\begin{array}{lllllllll}0.933 & 0.937 & 0.949 & 0.934 & 0.94 & 0.929 & 0.96 & 0.906 & 0.935 \\ 0.078 & 0.009 & 0.005 & 0.012 & 0.009 & 0.008 & 0.006 & 0.019 & 0.008\end{array}$

$\begin{array}{lllllllll}0.207 & 0.189 & 0.202 & 0.218 & 0.176 & 0.227 & 0.194 & 0.281 & 0.201 \\ 0.473 & 0.446 & 0.464 & 0.452 & 0.467 & 0.461 & 0.480 & 0.356 & 0.464 \\ 0.155 & 0.233 & 0.205 & 0.171 & 0.199 & 0.164 & 0.197 & 0.238 & 0.182 \\ 0.164 & 0.132 & 0.129 & 0.161 & 0.159 & 0.147 & 0.129 & 0.125 & 0.153\end{array}$

$\begin{array}{lcccccccc}0.135 & 0.059 & 0.099 & 0.077 & 0.087 & 0.132 & 0.094 & 0.038 & 0.109 \\ 0.143 & 0.062 & 0.113 & 0.107 & 0.102 & 0.129 & 0.146 & 0.119 & 0.115 \\ 0.158 & 0.091 & 0.141 & 0.132 & 0.131 & 0.139 & 0.194 & 0.138 & 0.135 \\ 0.239 & 0.225 & 0.23 & 0.253 & 0.255 & 0.212 & 0.237 & 0.225 & 0.234 \\ 0.156 & 0.196 & 0.185 & 0.17 & 0.164 & 0.175 & 0.149 & 0.151 & 0.171 \\ 0.072 & 0.142 & 0.108 & 0.101 & 0.097 & 0.094 & 0.083 & 0.138 & 0.096 \\ 0.098 & 0.227 & 0.124 & 0.161 & 0.164 & 0.118 & 0.097 & 0.194 & 0.142\end{array}$

$\begin{array}{lllllllll}0.121 & 0.107 & 0.148 & 0.086 & 0.118 & 0.114 & 0.154 & 0.100 & 0.116\end{array}$

$\begin{array}{lllllllll}0.192 & 0.149 & 0.211 & 0.161 & 0.166 & 0.188 & 0.226 & 0.181 & 0.177\end{array}$

$\begin{array}{lllllllll}0.089 & 0.090 & 0.088 & 0.080 & 0.081 & 0.099 & 0.060 & 0.106 & 0.090\end{array}$

$\begin{array}{lllllllll}0.137 & 0.146 & 0.123 & 0.167 & 0.144 & 0.136 & 0.126 & 0.169 & 0.140\end{array}$

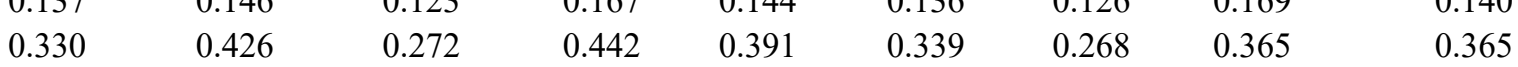


Organization ownership

For profit company/organization

Non-profit company/organization

0.694

Broader Public Sector

0.107

0.426

0.124

0.114

0.634

0.075

0.279

0.108

0.609

0.117

0.582

0.096

0.625

0.124

0.74

0.506

0.603

Government/Public Administration

0.103

$0.124 \quad 0.130$

0.161

0.091

0.144

0.11

$0.18 \quad 0.103$

0.09

0.083

0.206
0.144

0.177

c. Market/Industry Characteristics

Major Disruption at Workplace

No Disruption

$0.536 \quad 0.466$

Yes, Major Disruption

0.317

0.438

0.614

0.326

0.475

0.439

0.589

0.554

0.501

0.363

0.462

0.512

0.148

0.096

0.061

0.049

0.148

0.111

0.083

0.038

0.358

Industry

Agriculture, Forest, Fishing, Mining

Construction

Manufacturing (Durable/Non-Durable)

0.032

0.033

0.098

\subsection{9}

0.027

0.032

\subsection{4}

0.027

0.04

0.044

0.038
0.095

0.031

0.031

0.119

$0.068 \quad 0.103$

0.112

0.09

0.092

0.095

0.134

0.101

$\begin{array}{lll}0.051 & 0.037 & 0.038\end{array}$

$\begin{array}{ll}0.051 & 0.027 \\ 0.118 & 0.059\end{array}$

0.045

0.051

0.036

0.038
0.081

$0.039 \quad 0.011$

0.029

0.13

0.084

0.037

0.081

0.012

$0.072 \quad 0.027$

$0.101 \quad 0.034$

0.049

0.067

0.038

$0.131 \quad 0.038$

$0.109 \quad 0.171$

0.081

0.076

0.08

0.151

$\begin{array}{ll}0.113 & 0.145 \\ 0.101 & 0.136\end{array}$

0.113
0.136

0.103

0.138

$\begin{array}{lll}0.098 & 0.081 & 0.138\end{array}$

0.131

$0.091 \quad 0.173$

0.114

$0.135 \quad 0.138$

d. Hard-to-Observe Worker Attributes

Likes to Move Jobs

Belief in the Free Market

4.185

3.014

3.163

3.040

3.095

3.198

3.211

3.319

4.456

3.145

694

1,347

642

1,400

1,000

1,817

224

2,042

Notes: Data taken from the four-country State of Employment Relations Survey (SWERS) conducted in 2016. Sample covers all British respondents working in paid employment at the time of survey aged 18-64. 
Table 4: Sample Employee Satisfaction Scores By Type of Workplace Representation and HR system Amongst Employees in Britain, 2016

\begin{tabular}{|c|c|c|c|c|c|c|c|c|}
\hline & \multicolumn{7}{|c|}{ Employee Satisfaction Ratings (1 to 7 ) } & \multirow[b]{2}{*}{$\begin{array}{c}\text { Overall } \\
\text { Satisfaction } \\
\text { [Raw Diff. }\end{array}$} \\
\hline & Sample Mean & \multicolumn{2}{|c|}{$\begin{array}{c}\text { Satisfaction } \\
\text { with Job/Work }\end{array}$} & \multicolumn{2}{|c|}{$\begin{array}{l}\text { Satisfaction with } \\
\text { Management }\end{array}$} & \multicolumn{2}{|c|}{$\begin{array}{c}\text { Overall } \\
\text { Satisfaction }\end{array}$} & \\
\hline & {$[1]$} & \multicolumn{2}{|c|}{$[2]$} & \multicolumn{2}{|c|}{ [3] } & \multicolumn{2}{|c|}{ [4] } & {$[5]$} \\
\hline & & Mean & St. Dev & Mean & St. Dev & Mean & St. Dev & \\
\hline Overall & 1.00 & 4.40 & 1.31 & 4.32 & 1.38 & 4.36 & 1.28 & na \\
\hline 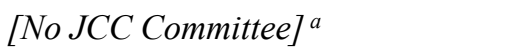 & 0.69 & 4.05 & 1.33 & 3.96 & 1.42 & 4.01 & 1.32 & $0.70 * * *$ \\
\hline Joint Consultative Committee (JCC) & 0.31 & 4.73 & 1.30 & 4.67 & 1.33 & 4.70 & 1.25 & {$[10.47]$} \\
\hline [No Union] & 0.66 & 4.39 & 1.31 & 4.36 & 1.37 & 4.38 & 1.29 & $-0.05 * *$ \\
\hline Union Representation (Union) & 0.34 & 4.42 & 1.30 & 4.25 & 1.40 & 4.33 & 1.28 & {$[5.21]$} \\
\hline [No HIHR] & 0.51 & 3.63 & 1.12 & 3.43 & 1.10 & 3.53 & 1.01 & $1.71 * * *$ \\
\hline High Involvement HR (HIHR) & 0.49 & 5.21 & 0.97 & 5.27 & 0.96 & 5.24 & 0.90 & {$[15.75]$} \\
\hline [No Union $x$ No Committee] ${ }^{b}$ & 0.39 & 4.05 & 1.36 & 4.02 & 1.43 & 4.03 & 1.34 & $0.61 * * *$ \\
\hline JCC x Union & 0.18 & 4.68 & 1.38 & 4.57 & 1.40 & 4.63 & 1.32 & [36.29] \\
\hline$\left[\right.$ Non-Committee $x$ No HIHR] ${ }^{b}$ & 0.35 & 3.48 & 1.18 & 3.29 & 1.18 & 3.38 & 1.09 & $1.93 * * *$ \\
\hline JCC x HIHR & 0.29 & 5.30 & 0.98 & 5.33 & 0.96 & 5.32 & 0.90 & {$[10.62]$} \\
\hline 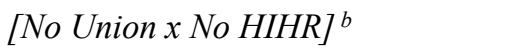 & 0.33 & 3.57 & 1.12 & 3.44 & 1.10 & 3.51 & 1.02 & $1.71 * * *$ \\
\hline Union $\mathrm{x}$ HIHR & 0.16 & 5.21 & 1.03 & 5.23 & 1.03 & 5.22 & 0.97 & [31.57] \\
\hline$[\text { No Union } x \text { No HIHR } x \text { No JCC }]^{b}$ & 0.24 & 3.39 & 1.17 & 3.29 & 1.18 & 3.34 & 1.10 & $2.01 * * *$ \\
\hline JCC x Union $\mathrm{x}$ HIHR & 0.11 & 5.35 & 1.05 & 5.35 & 1.06 & 5.35 & 1.00 & {$[22.02]$} \\
\hline
\end{tabular}

Notes: Data taken from State of Employment Relations Survey (SWERS). Sample covers all British respondents working in paid employment at the time of survey aged 18-64. Last column reports ‘raw' differences between main and excluded reference categories for overall satisfaction rating scores. The numbers in brackets are t-statistics. All differences are significant at 0.001 level. ${ }^{a}$ The excluded reference category also includes 'don't know' responders. These cases are included in regression analyses as a separate category. Analyses were conducted with the don't know respondents in as well as out of the estimates and no appreciable difference in the estimates was found. These results are available upon request.. ${ }^{b}$ The included and excluded reference categories do not sum to 1 because they are not inclusive of all employees having at least one of the interacted terms present. 
Table 5: Employee-level Regressions of Overall Workplace Satisfaction on Presence of Joint Consultative Committee, Union Recognition and High-Involvement HR in Britain, 2016

Dependent Variable: Overall Workplace Satisfaction Rating ( 1 to 7 score) [mean=4.36]

\begin{tabular}{|c|c|c|c|c|c|c|c|c|}
\hline & \multirow[b]{2}{*}{$(1)$} & & & & & & & \\
\hline & & (2) & (3) & (4) & (5) & (6) & (7) & $(8)$ \\
\hline \multirow{2}{*}{ Joint consultative committee (JCC) } & $0.187 * * *$ & $0.209 * * *$ & $0.237 * * *$ & $0.242 * * *$ & $0.235 * * *$ & $0.271 * * *$ & $0.286 * * *$ & $0.288 * * *$ \\
\hline & $(0.0398)$ & $(0.0408)$ & $(0.0426)$ & $(0.0410)$ & $(0.0813)$ & $(0.0817)$ & $(0.0812)$ & $(0.0820)$ \\
\hline \multirow[t]{2}{*}{ Union representation (Union) } & 0.0147 & 0.0240 & 0.00165 & 0.0269 & 0.0957 & 0.115 & 0.113 & 0.115 \\
\hline & $(0.0340)$ & $(0.0367)$ & $(0.0458)$ & $(0.0365)$ & $(0.0758)$ & $(0.0783)$ & $(0.0775)$ & $(0.0778)$ \\
\hline \multirow[t]{2}{*}{ High involvement human resources (HIHR) } & $1.215^{* * *}$ & $1.203 * * *$ & $1.198 * * *$ & $1.171 * * *$ & $1.307 * * *$ & $1.307 * * *$ & $1.266 * * *$ & $1.265 * * *$ \\
\hline & $(0.0323)$ & $(0.0327)$ & $(0.0415)$ & $(0.0332)$ & $(0.0624)$ & $(0.0626)$ & $(0.0633)$ & $(0.0628)$ \\
\hline \multirow[t]{2}{*}{ Union_x_JCC } & & & & & -0.163 & -0.173 & -0.142 & -0.135 \\
\hline & & & & & $(0.123)$ & $(0.124)$ & $(0.123)$ & $(0.123)$ \\
\hline \multirow[t]{2}{*}{ HIHR_x_JCC } & & & & & -0.0981 & -0.114 & -0.092 & -0.108 \\
\hline & & & & & $(0.1004)$ & $(0.100)$ & $(0.100)$ & $(0.1007)$ \\
\hline \multirow[t]{2}{*}{ Union_x_HIHR } & & & & & $-0.219 *$ & $-0.230 *$ & $-0.232 *$ & $-0.230^{*}$ \\
\hline & & & & & $(0.1217)$ & $(0.1227)$ & $(0.1203)$ & $(0.119)$ \\
\hline \multirow[t]{2}{*}{ Union_x_HIHR_x_JCC } & & & & & $0.327 *$ & $0.317 *$ & $0.298 *$ & $0.298 *$ \\
\hline & & & & & $(0.172)$ & $(0.172)$ & $(0.171)$ & $(0.169)$ \\
\hline Worker Characteristics & $\mathrm{Y}$ & $\mathrm{Y}$ & $\mathrm{Y}$ & $\mathrm{Y}$ & $\mathrm{Y}$ & $\mathrm{Y}$ & $\mathrm{Y}$ & $\mathrm{Y}$ \\
\hline Workplace Characteristics & & $\mathrm{Y}$ & $\mathrm{Y}$ & $\mathrm{Y}$ & & $\mathrm{Y}$ & $\mathrm{Y}$ & $\mathrm{Y}$ \\
\hline Market/Industry Characteristics & & & $\mathrm{Y}$ & $\mathrm{Y}$ & & & $\mathrm{Y}$ & $\mathrm{Y}$ \\
\hline Hard-to-Observe Individual Characteristics & & & & $\mathrm{Y}$ & & & & $\mathrm{Y}$ \\
\hline Observations & 2,042 & 2,042 & 2,042 & 2,042 & 2,042 & 2,042 & 2,042 & 2,042 \\
\hline R-squared & 0.460 & 0.468 & 0.481 & 0.491 & 0.462 & 0.471 & 0.482 & 0.487 \\
\hline
\end{tabular}

Robust standard errors in parentheses

$* * * \mathrm{p}<0.01, * * \mathrm{p}<0.05, * \mathrm{p}<0.1$ 
Appendix Table A1: Employee-level Regressions of Job Satisfaction on Presence of Joint Consultative Committee, Union Recognition and High-Involvement HR in Britain, 2016

Dependent Variable: Job Satisfaction Rating (1 to 7 score) [mean=4.40]

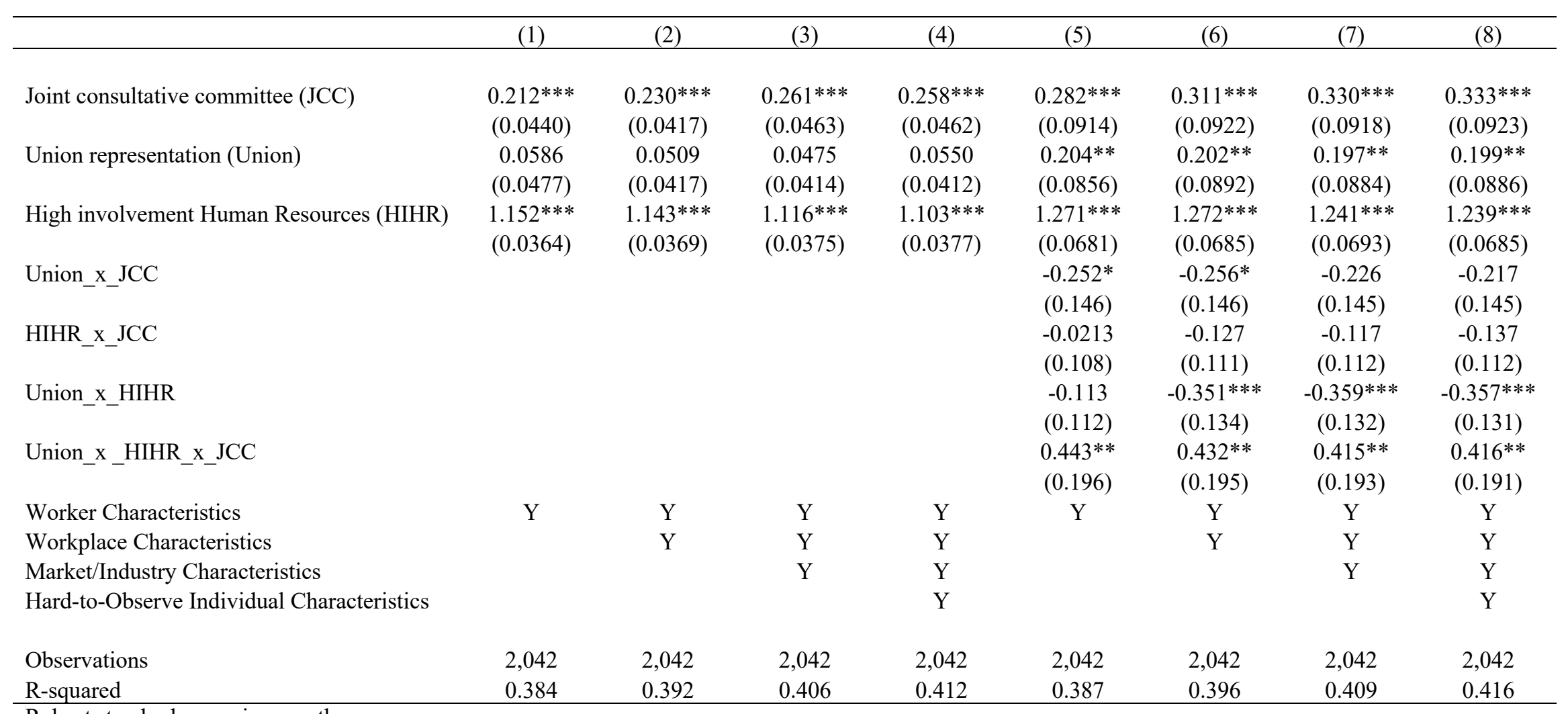

Robust standard errors in parentheses.

$* * * \mathrm{p}<0.01, * * \mathrm{p}<0.05, * \mathrm{p}<0.1$ 
Appendix Table A2: Employee-level Regressions of Satisfaction with Management on Presence of Joint Consultative Committee, Union Recognition and High-Involvement HR in Britain, 2016

Dependent Variable: Management Satisfaction Rating (1 to 7 score) [mean=4.32]

\begin{tabular}{|c|c|c|c|c|c|c|c|c|}
\hline & $(1)$ & (2) & (3) & (4) & $(5)$ & (6) & $(7)$ & $(8)$ \\
\hline Joint consultative committee (JCC) & $\begin{array}{c}0.163 * * * \\
(0.0410)\end{array}$ & $\begin{array}{c}0.188 * * * \\
(0.0419)\end{array}$ & $\begin{array}{c}0.223^{* * *} * \\
(0.0420)\end{array}$ & $\begin{array}{c}0.221 * * * \\
(0.0421)\end{array}$ & $\begin{array}{l}0.189 * * \\
(0.0846)\end{array}$ & $\begin{array}{c}0.223 * * * \\
(0.0839)\end{array}$ & $\begin{array}{c}0.241 * * * \\
(0.0841)\end{array}$ & $\begin{array}{c}0.243 * * * \\
(0.0849)\end{array}$ \\
\hline Union representation (Union) & $\begin{array}{c}-0.0291 \\
(0.0358)\end{array}$ & $\begin{array}{c}-0.002 \\
(0.0385)\end{array}$ & $\begin{array}{c}-0.006 \\
(0.0382)\end{array}$ & $\begin{array}{c}-0.010 \\
(0.0383)\end{array}$ & $\begin{array}{l}-0.0133 \\
(0.0802)\end{array}$ & $\begin{array}{c}0.0278 \\
(0.0802)\end{array}$ & $\begin{array}{c}0.0296 \\
(0.0815)\end{array}$ & $\begin{array}{c}-0.0309 \\
(0.0818)\end{array}$ \\
\hline High involvement HR (HIHR) & $\begin{array}{c}1.279 * * * \\
(0.0337)\end{array}$ & $\begin{array}{c}1.264 * * * \\
(0.0340)\end{array}$ & $\begin{array}{c}1.226^{* * *} \\
(0.0344)\end{array}$ & $\begin{array}{c}1.219 * * * \\
(0.0348)\end{array}$ & $\begin{array}{c}1.342 * * * \\
(0.0653)\end{array}$ & $\begin{array}{c}1.342^{* * *} \\
(0.0655)\end{array}$ & $\begin{array}{c}1.291 * * * \\
(0.066)\end{array}$ & $\begin{array}{c}1.290 * * * \\
(0.0658)\end{array}$ \\
\hline Union_x_JCC & & & & & $\begin{array}{c}-0.0746 \\
(0.127)\end{array}$ & $\begin{array}{r}-0.0903 \\
(0.128)\end{array}$ & $\begin{array}{c}-0.0590 \\
(0.127)\end{array}$ & $\begin{array}{c}-0.0542 \\
(0.127)\end{array}$ \\
\hline HIHR_x_JCC & & & & & $\begin{array}{r}-0.0831 \\
(0.104)\end{array}$ & $\begin{array}{c}-0.1008 \\
(0.104)\end{array}$ & $\begin{array}{c}-0.0688 \\
(0.104)\end{array}$ & $\begin{array}{l}-0.0801 \\
(0.104)\end{array}$ \\
\hline Union_x_HIHR & & & & & $\begin{array}{c}-0.0932 \\
(0.124)\end{array}$ & $\begin{array}{c}-0.109 \\
(0.127)\end{array}$ & $\begin{array}{l}-0.105 \\
(0.124)\end{array}$ & $\begin{array}{c}-0.054 \\
(0.127)\end{array}$ \\
\hline Union_x_HIHR_x_JCC & & & & & $\begin{array}{c}0.212 \\
(0.176)\end{array}$ & $\begin{array}{c}0.202 \\
(0.178)\end{array}$ & $\begin{array}{c}0.180 \\
(0.176)\end{array}$ & $\begin{array}{c}0.181 \\
(0.175)\end{array}$ \\
\hline Worker Characteristics & $\mathrm{Y}$ & $\mathrm{Y}$ & $\mathrm{Y}$ & $\mathrm{Y}$ & $\mathrm{Y}$ & $\mathrm{Y}$ & $\mathrm{Y}$ & $\mathrm{Y}$ \\
\hline Workplace Characteristics & & $\mathrm{Y}$ & $\mathrm{Y}$ & $\mathrm{Y}$ & & $\mathrm{Y}$ & $\mathrm{Y}$ & $\mathrm{Y}$ \\
\hline Market/Industry Characteristics & & & $\mathrm{Y}$ & $\mathrm{Y}$ & & & $\mathrm{Y}$ & $\mathrm{Y}$ \\
\hline Hard-to-Observe Individual Characteristics & & & & Y & & & & $\mathrm{Y}$ \\
\hline Observations & 2,042 & 2,042 & 2,042 & 2,042 & 2,042 & 2,042 & 2,042 & 2,042 \\
\hline R-squared & 0.461 & 0.472 & 0.484 & 0.486 & 0.462 & 0.473 & 0.485 & 0.487 \\
\hline
\end{tabular}

Robust standard errors in parentheses

$* * * \mathrm{p}<0.01, * * \mathrm{p}<0.05, * \mathrm{p}<0.1$ 
Figure A1: Moderating relationship of HIHR and Union presence on the JCC-job satisfaction relationship (three-way interaction with binary moderators)

$\neg(1)$ Yes Union, Yes HIHR $\multimap$ (2) Yes Union, No HIHR $\rightarrow \square(3)$ No Union, Yes HIHR $\rightarrow$-(4) No Union, No HIHR

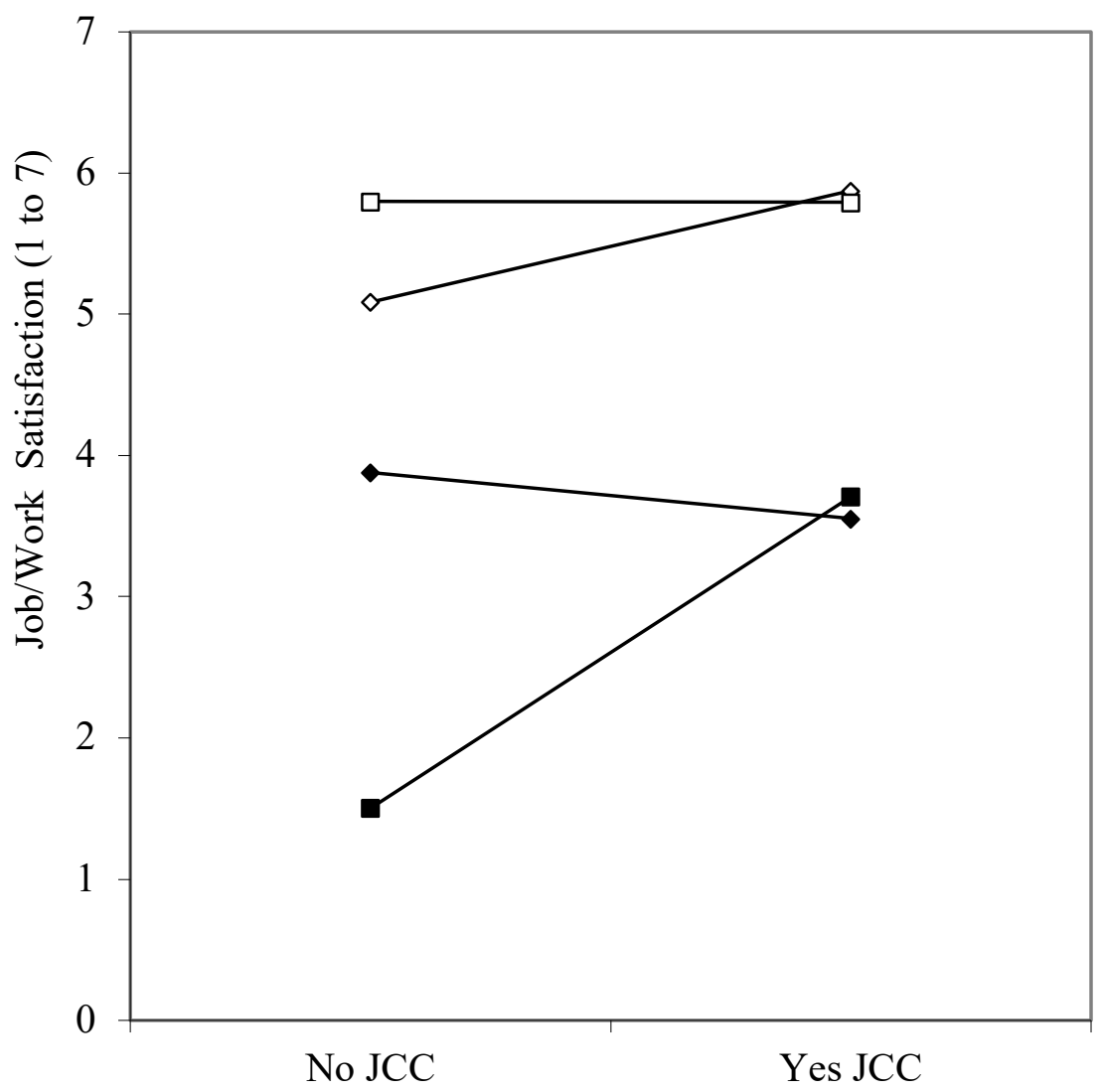


Figure A2: Moderating relationship of HIHR and Union presence on the JCC-satisfaction with management relationship (three-way interaction with binary moderators)

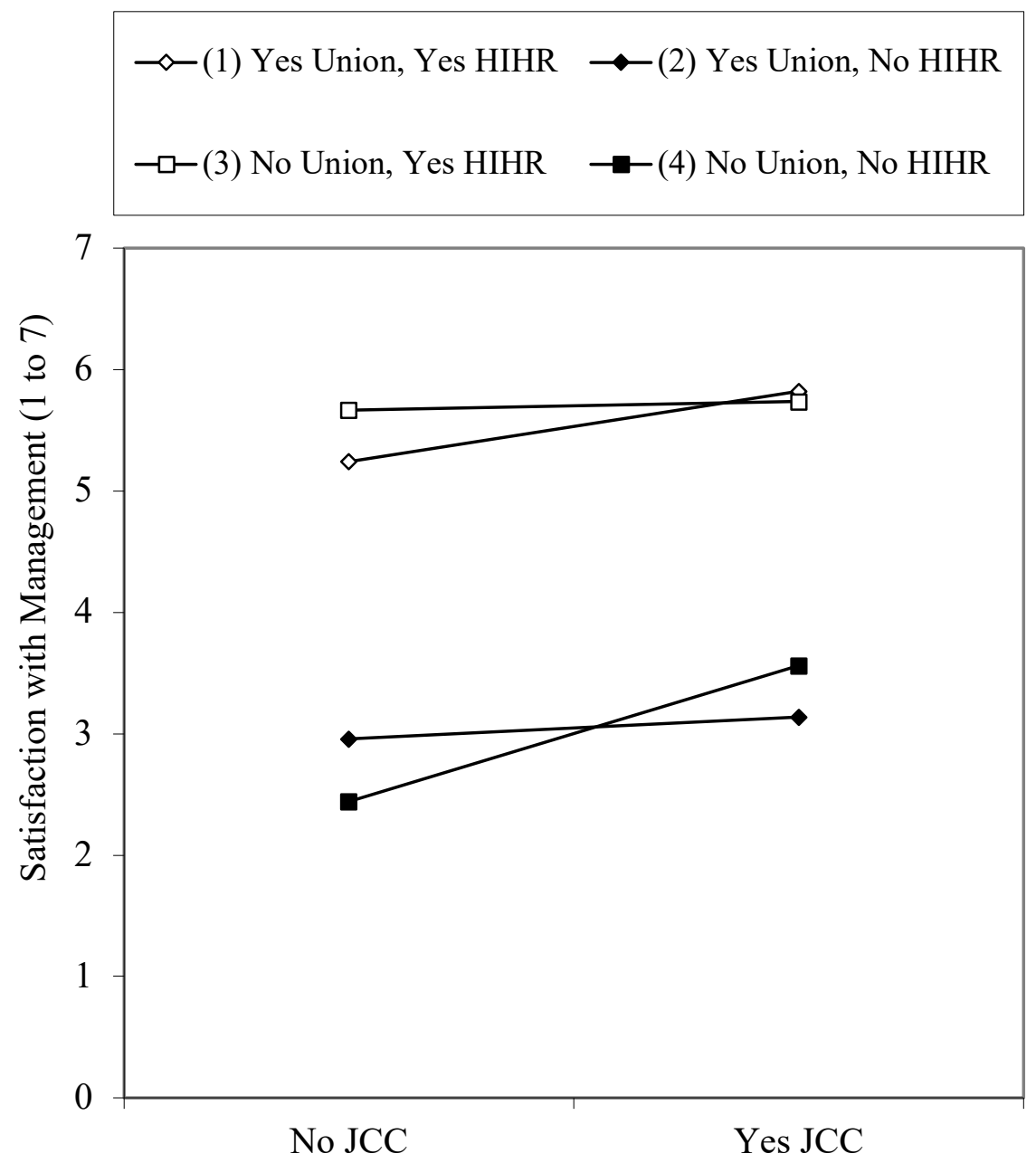

